\title{
Corporate Social Performance and Managerial Labor Market
}

\begin{abstract}
This paper examines the impact of a firm's social performance on the CEO's employment prospects. We track departing CEOs' subsequent employment records and find that the social performance of their previous employers improves their labor market outcomes. These CEOs are more likely to find a new executive position, and the new employer is more likely to be a publicly traded company. For the subsample of CEOs finding new executive positions at public firms, we find that a CEO whose previous employer has stronger social performance is more likely to move up to a larger firm. Finally, using a Cox proportional hazard model, we find that strong social performance of the previous employer helps CEOs find their next executive positions sooner. Overall, our results suggest that corporate social performance enhances CEOs' labor market potentials.
\end{abstract}

Keywords: Managerial labor market, Corporate social responsibility, CEO turnover 


\section{Introduction}

A large stream of literature in economics, finance, and accounting suggests that future labor market prospects affect managerial decision making at their current employers (e.g., Fama 1980; Holmstrom 1999). Managers' future labor market prospects should depend on their ability. Absent perfect information about managerial ability, the labor market is likely to take a firm's current and past performance as a signal of the quality of its CEO. Prior research suggests that potential employers use corporate financial performance to assess external executive hires. That is, a firm's superior financial performance significantly enhances its executives' job market prospects (Fee and Hadlock 2003), and financial distress and corporate failures substantially reduce the chances of CEOs securing comparable positions after departure (Gilson 1989; Houston and James 1993; Cannella, Jr., Fraser, and Lee 1995). There is also evidence that the external labor market penalizes managerial misconduct in reporting financial results (Desai, Hogan, and Wilkins 2006).

While prior research has primarily focused on financial results as a measure of corporate performance, recent studies show that various stakeholders, such as some institutional shareholders, have been increasingly focusing on social performance as a performance metric (e.g., Dimson, Karakaş, and Li 2015). Over the last decade, both the number of shareholder proposals on environmental and social issues filed with the SEC and the approval rates for these proposals have substantially increased (e.g., Glac 2014; Welsh and Smith 2011; Flammer 2015). Asset managers worldwide in charge of trillions of dollars incorporate environmental, social, and governance concerns into their investing decisions (Dimson, Karakaş, and Li 2015). Substantial economic resources are allocated to socially responsible corporate activities (Hong, Kubik, and Scheinkman 2012). Despite its growing significance, there is no evidence so far on whether and how the managerial labor market considers a firm's social performance in assessing managerial quality. 
We address this question by examining the impact of corporate social performance on the likelihood of departing CEOs obtaining new executive positions and the gap between employment.

Socially responsible investments can be value enhancing or value destroying for shareholders. Depending on the value implications of such activities, social performance can convey different information about managerial quality. Classical economic theory suggests that firms should not internalize the negative externalities they exert on non-shareholding stakeholders such as communities, employees, or the environment (e.g., Pigou 1920). Friedman's (1970) wellknown comments in his New York Times article argue that "the social responsibility of business is to increase its profits." Extending this view, some believe that investment in corporate social responsibility (CSR) is a manifestation of agency problems inside the firm (Cheng, Hong, and Shue 2016; Masulis and Reza 2015). This view suggests that managers engage in CSR activities to benefit themselves at the expense of shareholders (Kruger 2015). In this scenario, CSR engagement is likely viewed as a negative indicator of CEO quality and should impair CEOs' labor market prospects.

Two other views of CSR, as summarized by Benabou and Tirole (2010), suggest a positive impact of CSR on firm value. One view is that CSR practices allow management to take a longterm perspective and maximize intertemporal profits, consistent with shareholder interests. Another view is that CSR activities are a form of delegated philanthropy, which maximizes shareholder welfare and serves as an efficient channel to express personal values on behalf of firms' investors (Hart and Zingales 2017). Consistent with the implications of these two views, a number of studies provide examples of mechanisms through which CSR can enhance shareholder wealth (Edmans 2011; Dimson, Karakas, and Li 2015; Derwall, Guenster, Bauer, and Koedijk 2005; Flammer 2015; Servaes and Tamayo 2013; Dowell, Hart, and Yeung 2000). Under these views, 
corporate social performance can help CEOs develop a reputation as high-quality managers creating shareholder value. Furthermore, to the extent that corporate CSR policies reveal managers' altruism or a belief of doing the right thing (Benabou and Tirole 2006; Gao, Lisic and Zhang 2014), a firm's social performance can signal CEOs' high ethical standards. All these arguments indicate that CEOs with strong social performance should be rewarded with better job market prospects.

We examine the empirical question of whether a firm's social performance is related to the CEO's future job market opportunities by compiling a sample of CEO departures in U.S. public firms from 1993 to 2012. We end the sample period in 2012 to allow time for departing CEOs to find new jobs. We limit the age of the departing CEOs to be under 60 to exclude departures due to retirements. Then, through a manual search, we track their post-departure employment records up to 2016 .

We assess a firm's social performance with a summary CSR score that reflects various aspects of social responsibility using the social ratings data issued by MSCI ESG STATS (MSCI hereafter). Similar to prior research (e.g., Gao et al. 2014), we classify a firm as having strong social performance if it has more CSR strengths than concerns. We estimate a linear probability model with industry and year fixed effects and find that CEOs leaving firms with strong social performance are more likely to secure new executive positions, after controlling for the size and financial performance of their previous employers and CEO characteristics such as age and tenure. Considering that executive positions at publicly traded companies are in general associated with higher visibility and better pay than comparable positions at privately held companies, we also capture managerial career prospects by the likelihood of obtaining an executive position at a public firm. Our analysis indicates that CEOs leaving firms with strong CSR performance are also more likely to be hired as executives by public firms. These results suggest that the managerial labor 
market rewards CEOs for their social performance. Our inference is robust to a number of alternative specifications, including measuring corporate social performance over different windows before CEO departures, using a conditional logit regression model, and controlling for general managerial ability following Custódio et al. (2013).

While the social performance of executives' previous employers has been pre-determined by the time they receive the new appointments, mitigating the concern for endogeneity to some extent, it is still possible that both corporate social performance and CEOs' career prospects are under the influence of some unobservable factors and exhibit a spurious correlation. To address this issue, we employ an instrumental variable approach. Similar to Cheng, Ioannou, Serafeim (2014), we use the industry level CSR performance as an instrument. As expected, we show that corporate social performance is highly correlated with the average CSR ratings of the industry. In the second stage regression, we continue to find a significant positive correlation between the instrumented social performance and the likelihood of CEOs securing new executive positions and the likelihood of their obtaining executive positions at publicly traded firms.

Next, we explore the subsample of CEOs who secure new executive positions at publicly listed firms, where we are able to collect more detailed information about the new employers. We find that CEOs whose former employers have strong social performance are more likely to move to companies that are larger than their former employers. To the extent executives at larger public firms enjoy more prestige and higher pay, such moves may be regarded as promotions. The results are therefore consistent with the managerial labor market rewarding CEOs for superior social performance at their previous employers.

Next, we examine whether social performance plays a role in determining the gap between executive employment. Ertimur et al. (2017) find an average gap of about two years between 
managerial employment and attribute the gap to labor market frictions and managerial skillset. Fee and Hadlock (2003) separate executives who jump immediately from a prior public employer to a new position from those with employment gaps and find evidence suggesting that the former outperform the latter in terms of financial results. Using a Cox proportional hazards model, we find that the employment gap is significantly shorter for CEOs leaving firms with strong social performance than for those from firms with weak social performance. The results are consistent with CEOs with a reputation of committing to social good having more favorable job market prospects.

Finally, we conduct two additional analyses. First, we explore the subsample of CEOs who secure new executive positions at publicly listed firms, where we are able to collect more detailed information about the new employers. We find that CEOs whose former employers have strong social performance are more likely to move to companies that are larger in size than their former employers. To the extent executives at larger public firms enjoy more prestige and higher pay, such moves may be regarded as promotions. The results are therefore consistent with the managerial labor market rewarding CEOs for superior social performance at their previous employers. Second, we separately examine voluntary vs. forced CEO turnovers. We find that CEOs whose former employers have strong social performance are more likely to find executive positions in general and at publicly firms if the CEOs leave their employers voluntarily. In contrast, we do not find these results for CEOs who are forced to leave the firm. These results reinforce the notion that superior social performance signals managerial ability in the labor market.

This study makes at least two contributions. First, we contribute to the literature on managerial labor market by providing new evidence that potential employers consider corporate social performance as an indicator of managerial quality and rewards socially conscious CEOs 
with favorable career prospects. Our findings add to prior studies where financial performance is the primary signal of CEO quality. As the demand of managerial labor market shapes CEO behavior, our findings have implications for understanding managerial incentives to engage in CSR practices.

Second, this study adds to the CSR literature by presenting additional evidence consistent with CSR engagements being viewed positively by shareholders. The managerial labor market can be a disciplinary mechanism that penalizes managerial misconduct in the form of ex-post settling up. Prior research finds evidence suggesting that the labor market is effective in terms of punishing CEO wrongdoings and differentiating between good and poor managerial performance (Desai, Hogan, and Wilkins 2006; Cannella, Fraser, and Lee 1995). Our finding that the labor market rewards CEOs' previous CSR engagement suggests that shareholders' overall view of CSR activities is positive. Previous CSR engagement can be informative about CEOs' ability to create shareholder value via social awareness and about their ethical standards.

The rest of the paper is organized as follows: Section 2 discusses the hypothesis development. Section 3 describes our sample and descriptive statistics. Section 4 reports empirical results. Section 5 concludes.

\section{Hypothesis development}

Fama (1980) characterizes managerial labor market as a principal disciplinary and incentive mechanism. Analytical research predicts that CEOs' concerns about labor market opportunities affect various managerial decisions including risk-taking, capital structure, and investment (e.g., Holmstrom and Ricart I Costa 1986; Scharfstein and Stein 1990; Hirshleifer and 
Thakor 1992; Holmstrom 1999). ${ }^{1}$ Empirical evidence on the managerial labor market, however, is limited relative to that on other managerial incentive devices such as the market for corporate control and executive compensation.

As managers' ability is not directly observable, the labor market likely assesses managerial talent based on observations of their output. Several empirical studies find evidence suggesting that the labor market uses financial performance as an indicator of managerial ability. Gilson (1989) and Houston and James (1993) detect severe external labor market consequences for managers whose firms become financially distressed. Fee and Hadlock (2003) construct a sample of top managers who move to new employers as CEOs and show that superior stock returns of previous employers are helpful, especially for managers who jump ship immediately and senior managers, who are perceived to be more accountable for the stock performance in original employers. Furthermore, there is evidence that the managerial labor market impounds refined information about previous financial performance when assessing managerial ability. Cannella, Jr., Fraser, and Lee (1995) find that managers associated with banks that failed for reasons arguably beyond the managers' control are more likely to regain comparable positions than managers at other failed banks, suggesting that the labor market can discriminate between good and bad managerial performance. Desai, Hogan, and Wilkins (2006) report that managers of firms issuing accounting restatements are significantly less likely to be rehired at comparable positions after departure than those of firms without restatements.

While the analytical and empirical literature on managerial labor market has focused on financial performance as an indicator of managerial quality, another corporate performance

\footnotetext{
${ }^{1}$ Several studies provide empirical evidence of the impact of career concerns in specialized labor market, such as fund managers and analysts (e.g., Chevalier and Ellison, 1999; Graham, 1999; Hong, Kubik, and Solomon, 2000; Hong and Kubik, 2003; Kempf, Ruenzi, and Thiele, 2009).
} 
metric — social performance — has attracted substantial shareholder attention in recent years. The Global Sustainable Investment Alliance (2016) estimates that \$22.9 trillion of professionally managed assets considers environmental, social and governance factors in portfolio selection and management, standing at 26 percent of all professionally managed assets worldwide. There is evidence that large institutional investors engage in dialogues with target companies and exercise ownership rights at shareholders' meetings to promote CSR practices, in addition to screening out irresponsible companies from their investment portfolios (Dimson, Karakas, and Li 2015). These activities suggest that shareholders are attaching an increasing importance to firms' social performance.

The value of CSR practices to shareholders, however, has been hotly debated; empirical evidence is also mixed. The early literature views social responsibility as a "donation" from shareholders to stakeholders that reduces profits (e.g., Friedman 1970). Some further argue that CSR practices are the outcome of agency conflicts between shareholders and managers (Jensen and Meckling 1976; Cheng, Hong, and Shue 2014; Masulis and Reza 2015). Masulis and Reza (2015), for example, find that corporate giving is positively associated with CEO charity preferences and negatively correlated with CEO shareholdings and corporate governance.

In contrast, other theories hold a positive view of CSR, arguing that CSR practices allow management to take a long-term perspective and maximize intertemporal profits, and that CSR activities can be an efficient form of delegated philanthropy on behalf of firms' stakeholders including shareholders (Benabou and Tirole 2010). A number of recent studies find evidence suggesting that CSR engagement can increase firm value by enhancing customer loyalty and product differentiation (Besley and Ghatak 2007; Albuquerque, Durnev, and Koskinen 2014; Servaes and Tamayo 2013), improving employee morale and facilitating talent retention (Edmans 
2012; Turban and Greening 1997), and attracting a broad clientele (Grossman and Sharpe 1986; Hong and Kacperczyk 2009; Dimson, Marsh, and Staunton 2015). Consistent with CSR activities increasing shareholder wealth, Dimson Karakas and Li (2015) show that target companies experience positive abnormal returns following successful CSR engagements initiated by large institutional investors.

If managers engage in CSR activities that benefit themselves at the expense of shareholders, we expect the labor market to discipline the managers through the ex-post settling up. That is, the labor market is likely to punish the CEOs by cutting their job market opportunities. However, if CSR activities create shareholder value while achieving social benefits, we expect the managerial labor market to reward CSR conscious CEOs with favorable career prospects. Strong corporate social performance can convey positive information about CEO quality in at least two ways. First, CEOs of CSR firms may be perceived as having the expertise to create shareholder wealth while balancing the needs of other stakeholders. With various stakeholders, including regulators, paying increasing attention to CSR activities, such expertise can be in high demand as a growing number of potential employers aim to achieve a balance between CSR and value maximization to reduce external pressure. Second, CSR activities are often associated with an image of integrity, which can reflect on personal qualities of CEOs who champion these activities. Benabou and Tirole (2006) argue that variations in prosocial behavior are partly driven by heterogeneity in agents' individual degrees of altruism and greed. Strong corporate social performance can thus be attributed to managerial altruism and help CEOs build a reputation of integrity. It is conceivable that individuals with high ethical standards and integrity are more likely to fulfill their fiduciary duty and less likely to expropriate shareholders to extract personal benefits. Potential employers may, therefore, consider executives of integrity to be valuable assets. Consistent with this argument, a Harvard 
Business Review survey reveals that integrity is one of the seven skills sought after in the C-suite (Groysberg 2014). This suggests that the labor market will reward socially conscious CEOs with better career prospects.

Given the contrasting predictions regarding social performance and signaling of management ability, we form the hypothesis in its null form:

H1: Social performance of the departing CEO's previous employer is unrelated to the CEO's future employment prospects.

\section{Data description and univariate analysis}

We start the sample by identifying CEO departures in U.S. public firms using information on both the Execucomp and BoardEx. Specifically, we flag potential turnovers when the identifications of CEO between two consecutive years differ. The last year that a CEO is with the previous employer is considered the turnover year. We restrict the sample to departing CEOs younger than 60 in their turnover year to exclude retirements.

For every departing CEO, we verify the accuracy of the employment data available in Execucomp and BoardEx and manually collect additional information about the CEO's employment at the firm he/she is leaving (labeled as the previous employer hereafter) and the firm he/she is joining (labeled as the subsequent employer hereafter). Information regarding the CEO's employment at the previous employer includes the date he/she becomes the CEO, the year he/she steps down from the CEO position, and any positions in the same firm after he/she steps down. For the CEO's subsequent employer, we gather information on the subsequent employer's name, the year he/she starts the new job, and the new job title. As future employment information is often 
missing in Exceucomp and BoardEx, we employ extensive manual collection using Google search, followed by Bloomberg and Linked-in searches for the subsequent positions of departing CEOs.

During the data collection process, we apply several filters to ensure that we have a clean sample of CEO turnovers where the departing CEOs were actively searching for a job: (1) we eliminate all cases where the CEO steps down and takes another position in the same company, often as the Chairman of the board; (2) we eliminate all CEO turnovers that are associated with mergers and spin-offs; (3) we remove all CEO change cases if the change is due to death or CEO health issues, and (4) we remove cases if CEOs find a job more than 15 years after their departure. To ensure the departing CEO has some impact on the CSR performance of the firm, we also identify and exclude turnovers of interim CEOs, that is, if the CEO tenure is less than a year. In the end, our data collection procedures result in a sample of 1,915 CEO turnover cases, spanning from 1993 to 2012.

We focus on turnovers of CEOs as opposed to executives that are in non-CEO positions for the following reasons. First, CEOs are likely to have more control over firms' CSR policies than other executives. Second, CEOs are likely to be in the spotlight to discuss their firms' CSR performance and get more credit for such efforts. It is therefore likely that potential employers attribute firms' CSR practices to their CEOs. We believe that the focus on CEOs provides a more powerful setting to test the relation between corporate social performance and managerial labor market prospects.

[Insert Table 1]

Table 1 presents the sample distributions. Panel A reports the distribution of CEO turnovers by year. We have fewer CEO turnover cases in the 1990s, potentially due to the limited coverage of Execucomp and BoardEx. The highest frequency appears in 2007, which can be related to the 
financial crisis. The second highest frequency appears in 2005. Anecdotes suggest that it may be related to the global governance reform. ${ }^{2}$ Panel B of Table 1 reports the industry distribution of the CEO turnover sample. The three industries with the most turnover cases are business equipment, finance, and healthcare, medical equipment, and drugs. Departing CEOs' age distribution is presented in Panel C. While there are 74 departing CEOs under age 40, the majority CEOs are over 50 years old. Panel D of Table 1 summarizes the types of CEOs' subsequent employers. The majority of these executives take new executive positions in private firms (944 out of 1915), followed by executive positions in public firms (281 out of 1915). Other less frequent fields include nonprofit organizations, education, politics and others. In 653 cases, no new employment information is available.

We obtain CSR ratings data from MSCI ESG STATS (previously called KLD) and construct an aggregate measure by calculating the total number of strengths minus the total number of concerns in the following categories: environment, community affairs, employees, diversity, human rights, and products. ${ }^{3}$ We refer to a firm as a CSR firm, that is, a firm with strong social performance, if it has more CSR strengths than CSR weakness in a year. All other firms are nonCSR firms. We capture (average) CSR performance over different windows: one year, two years and three years prior to the turnover. ${ }^{4}$ If a firm's CSR ratings are missing in any year, we use the CSR ratings for the other years in the relevant measurement window to classify whether a firm is CSR conscious or not. Similarly, if a CEO's tenure is shorter than the horizon of CSR measurement, our CSR measure is computed over the tenure of the CEO.

\footnotetext{
${ }^{2} \mathrm{http} / / /$ www.businesswire.com/news/home/20060518005074/en/Global-CEO-Turnover-Set-New-Record-2005

${ }^{3} \mathrm{We}$ exclude the measure of governance as it is a distinct measure, including the disclosure of a firm's CSR efforts etc.

${ }^{4}$ We also followed Servaes and Tamayo (2013) and use the maximum number of strengths and concerns in each category to adjust the CSR performance for each firm before aggregating the CSR index. Our inferences are unchanged.
} 
[Insert Table 2]

Table 2 summarizes the characteristics of departing CEOs' previous employers. In panel A, we report the percent of CSR conscious firms (i.e., CSR firms) measured over the most recent one, two and three years. Regardless of the horizon over which we measure CSR performance, about $30 \%$ of firms are classified as CSR firms. The average sample firms are large and nonprofitable with negative ROA and return. The mean market value of equity is $\$ 2.2$ billion. The departing CEOs are on average 47 years of old, with an average tenure of 6.4 years. About $2 \%$ of the sample firms announced restatement of financial reports.

In Panel B, we partition the sample by whether the previous employer is CSR conscious, determined based on its CSR performance of the most recent year before CEO departure, and compare the characteristics of the two resulting subsamples. Consistent with the literature, CSR firms are significantly larger and have better performance as measured by ROA (both with pvalues less than 1\%). There is no significant difference between the two groups of firms regarding return, executive tenure, or the likelihood of restatement.

We also report executives' future employment outcome for the two subsamples partitioned by whether the previous employer is CSR conscious. Of the 295 CEOs leaving CSR firms, 96 do not have a future executive job (32.5\%), five percent lower than that of CEOs leaving non-CSR firms (37.8\%), and the difference is statistically significant at the $10 \%$ level. Further, CEOs leaving CSR firms are more likely than CEOs leaving non-CSR firms to find a new executive position at a public firm (19.7\% and $13.8 \%$ for CSR firms and non-CSR firms). The difference is statistically significant at the $5 \%$ level. $^{5}$

\footnotetext{
${ }^{5}$ The comparison partitioned by CSR performance measured over the most recent two and three years are similar and not tabulated.
} 


\section{Research Design and Empirical analysis}

\subsection{CSR and favorable labor market outcome}

We construct the following regression model to test the relation between CSR performance and labor market prospects.

Labor Market Outcome $=\alpha_{0}+\beta_{1} \operatorname{CSRFIRM} M_{t}+\beta_{2} \log \left(\operatorname{SIZE}_{t}\right)+\beta_{3} R O A_{t}+\beta_{4} R E T_{t}+\beta_{5} \log (A G E)$

$+\beta_{6} \log ($ TENURE $)+\beta 7$ RESTATE + Year FE + Industry FE $+\varepsilon i, t$

The dependent variable captures whether departing CEOs receive favorable labor market outcomes. We use various measures to focus on different aspects of labor market outcomes. First, we define finding a new executive position (relative to not finding an executive position) as a favorable outcome, including getting another executive position at either a public firm or a private firm. If the departing CEOs take fulltime positions in institutions like non-profit organizations or universities, we also consider the case as the CEOs landing new jobs.

Second, as public firms are on average more visible and their executives are paid higher than private firms or other organizations, ${ }^{6}$ we next focus on whether departing CEOs could land an executive position in a public firm as the labor market outcome. Third, within the subsample of departing CEOs finding new executives positions in public firms, we examine whether CSR performance of the prior employer helps departing CEOs to obtain an executive position at a larger public firm than their previous employers.

We include a number of control variables following the prior literature. Fee and Hadlock (2003) show that firm size is positively associated with executives finding another executive position in a publicly-traded firm. This suggests that executives of larger firms are considered more desirable in the labor market, either due to these positions being signals of managerial quality or

\footnotetext{
${ }^{6} \mathrm{https} / / /$ chiefexecutive.net/widening-gap-public-private-company-ceo-pay_trashed/
} 
providing more opportunities to develop managerial expertise. They also show that superior stock market performance in the prior employer helps executives jump to CEO positions at new employers. Further, Rajgopal, Shevlin and Zamora (2006) use industry-adjusted ROA as a measure of CEO talent. We include both industry-adjusted stock returns and ROA as control variables for predicting labor market prospect. We also follow Fee and Hadlock (2003) and control for the age and tenure of departing CEOs, both of which have been shown to negatively impact the labor market prospect. Desai, Hogan, and Wilkins (2006) show that employment prospects of displaced executives (including chairman, CEO and president) are worse following a restatement. Whether a firm announces restatement (RESTATE) is included to account for potential different career outcome driven by accounting restatement. To capture the effects of year and industry on the labor market outcomes, we include both year and industry fixed effects in our regression model. To avoid the incidental parameter problem, we follow Kim, Shroff, Vyas, and Wittenberg-Moerman (2018) and estimate the regression as a linear probability model. ${ }^{7}$

[Insert Table 3]

Table 3 presents the estimation results of model (1). Standard errors are robust to accounting for potential heterogeneity. When CSR performance is measured over the most recent year, we observe that CSR FIRM has a positive and significant effect on the probability of CEOs finding a new job $(0.0711, \mathrm{p}$-value $<2 \%)$. This suggests CEOs leaving an employer with strong CSR performance in the year prior to departure are $7.11 \%$ more likely to find a new job than those leaving employers with weak CSR performance. When the CSR performance of the previous

\footnotetext{
${ }^{7}$ As pointed out in Kim et al. (2017), Greene's (2004) criticize the inclusion of fixed effects in non-linear models as it has two shortcomings. The first is a practical obstacle regarding the difficulty of computing the MLE of the coefficients of non-linear models with a large number of dummy variable coefficients; the second is incidental parameters problem that cast doubt on the statistical properties of the ML estimator. Therefore, we do not estimate model (1) as a non-linear model. However, our findings are robust to estimating a probit or a logit regression.
} 
employer is measured over the most recent two and three years, we similarly find a positive and significant coefficient on $\operatorname{CSR} \operatorname{FIRM}(0.0833,0.0721$, with p-values $<1 \%)$. Untabulated results using probit and logit models yield similar inferences. The results support our hypothesis that the CSR performance of the previous employer helps departing CEOs in the job search.

Consistent with industry-adjusted $R O A$ being a proxy for the talent of improving firm performance, leaving a firm with superior financial performance increases the probability of executives finding the next job. Other variables with a significant influence in job search include the age and tenure of the departing CEO; older CEOs and those with longer tenure are less likely to find a new job. The size of the previous employer, market return, and the incidence of restatement are not significantly correlated with CEOs' career outcome.

Next, we examine whether the CSR performance of the previous employer affects the likelihood of departing CEOs becoming executives in another public firm and report the results in Table 4. The coefficient on CSR FIRM is positive and significant for all measuring horizons of CSR performance. This is consistent with the univariate analysis, suggesting that the CSR performance of the previous employers increases the likelihood of departing CEOs becoming executives in other public firms. Similar to the results in Table 3, departing CEO who are older and those with longer tenure are less likely to find a position in a public firm. Unlike in the results in Table 3, the financial performance of the previous firm does not seem to significantly improve CEOs' chance of being rehired as executives in other public firms. Together with the inference from Table 3, the results provide support for our prediction that departing executives benefit when their previous employer outperform in CSR.

[Insert Table 4] 


\subsection{Robustness checks}

In this section, we perform a series of robustness checks and report the results in Table 5. First, we use a continuous measure of CSR performance, that is, the total number of strengths minus the number of concerns (CSR SCORE), in place of the dummy variable used in Tables 3 and 4. As shown in the first three columns in Panel A, the coefficient on CSR SCORE is positive and significantly associated with the probability of finding a new job, consistent with the inference from Table 3. Also similar to Table 4, we get positive and significant coefficients on CSR SCORE from Columns (4) through (6) when the career outcome is measured as the likelihood of securing a new executive job at a public firm.

[Insert Table 5]

In panel B, we use an alternative measure of CSR performance following Servaes and Tamayo (2013), who adjust the number of strengths and concerns by the maximum possible number within each CSR category. We obtain similar results using both the continuous and the dummy variable version of the variable (Adj. CSR FIRM) and only report the latter in Panel B for brevity. As in Tables 3 and 4, executives from CSR firms as identified by Adj. CSR FIRM are more likely to find a new job and find an executive position in a public firm.

In Panel C, we also extend the horizon over which CSR performance is measured to five years prior to turnover and the entire tenure of the departing CEO. As these two measuring horizons are longer than what we have used, CEOs' earlier CSR performance is also taken into consideration. The coefficient on the dummy variable CSR FIRM is positive and significant for all four columns, suggesting that leaving a CSR conscious employer increases the probability of finding the next job or the next executive position in a public firm by $5-6 \%$, when CSR performance is measured over the most recent five years, or the entire duration of CEO tenure. 
One issue in using a linear probability model is that the predicted probability may not be a value between zero and one. Although we obtain similar results if logit or probit regressions are used, the results are subject to the incidental parameters problem as we have both industry and year fixed effects. In Panel D, we report the results from estimating a conditional logit regression. Consistent with our earlier results, the coefficient on CSR FIRM is positive and significant at the $1 \%$ level across different horizons of measuring CSR performance of the previous employer and for both the probability of finding the new job or finding an executive position in a public firm, lending additional support for the robustness of our earlier results.

Although we have controlled for managerial ability as reflected in ROA and stock returns, it is still possible that the career path of the departing CEOs depends on certain skills they have acquired over time. In the event that such skills are not captured by financial or stock performance and valued by future employers, it is an omitted variable, which is a problem if it correlates with the CSR performance of the previous employer. We thus control for general managerial ability using Custodio et al.'s (2013) measure which captures executives' accumulated managerial ability based on their work experience that is transferable to other firms or industries (GENERAL ABILITY). ${ }^{8}$ Panel E of Table 5 reports the regression results after controlling for GENERAL ABILITY. Similar to the results in Tables 3 and 4, the coefficient estimates on CSR FIRM remain mostly positive and significant. GENERAL ABILITY is significantly positively correlated with the probability of finding a new job and the probability of finding an executive position in a public firm, consistent with the notion that CEOs with more general ability are more likely to find jobs when they leave their current position. Results in this table indicate that CSR performance cannot

\footnotetext{
${ }^{8}$ They extract the first factor from a principal component analysis that includes five proxies for executives' professional skills: past number of positions, number of firms, number of industries, whether the CEO held an executive position at a different company, and whether the CEO worked for a conglomerate.
} 
be subsumed by managers' general ability and is an important determinant of executives' job market outcomes.

\subsection{Endogeneity of CSR Performance}

Although the results in the previous sections support the conjecture that being CSRconscious improves CEOs' labor market prospects, one concern about the results is the issue of endogeneity. Firms' CSR performance can be correlated with some relevant but unobservable omitted variables, which also affect executives' job market opportunities. To address the potential endogeneity issue, we employ the instrumental variables approach to test our prediction.

We use the average CSR performance of peer firms in the same 2-digit SIC industry (Industry CSR) as an instrumental variable for the CSR performance of CEOs' previous employers. ${ }^{9}$ Conceptually, the industry average CSR performance should correlate with firm-level CSR performance. However, industry CSR performance should not affect a particular executive's job market outcomes directly, unless it is through the CSR performance of the previous employer.

\section{[Insert Table 6]}

Panel A of Table 6 presents the first stage regression, which regresses CSR FIRM on Industry CSR and all the control variables. We observe that the coefficient estimates for Industry CSR are all positive and highly significant across all measuring horizons for CSR FIRM, which suggest the relevance condition is satisfied. The first-stage F-statistics for the test that the instrument can be excluded from the first-stage regression are all above ten, alleviating concerns for weak instrument. Panel B of Table 6 reports the results of the second stage regressions. The first three columns present the results with finding a new job as the favorable labor market outcome

\footnotetext{
${ }^{9}$ We also consider religion rank and blue state as instrumental variable candidates. However, they appear to be weak instruments for our sample in the first stage analysis.
} 
and the last three columns presents the results with finding a job in a public firm as the favorable labor market outcome. Consistent with the results reported in Table 3 and 4, the coefficient estimates on CSR FIRM are all positive and significant, suggesting that being CSR-conscious enhances executives' position in the labor market.

\subsection{CSR and the duration of job search}

The focus of the previous section is on whether social performance of the previous employer helps increase the likelihood of executives finding a new job. We next employ a duration analysis, which can address the concern of biased estimates in the presence of censored data. The data on future employment of executives are right censored, because we end the search of news for their new jobs as of December 2016, and therefore could not observe what happens after that. We employ both a non-parametric and a semi-parametric method to examine the effect of CSR performance on the occurrence and the speed for CEOs to find another executive position.

\subsubsection{Using a Non-parametric method}

We first use the Kaplan-Meier estimator, a non-parametric approach, to estimate the survivor function in the presence of right censoring. In particular, the Kaplan-Meier estimator for the survivor function is

$$
\hat{S}(t)=\prod_{i: t_{i} \leq t}\left(\frac{n_{i}-d_{i}}{n_{i}}\right),
$$

where $d_{i}$ is the number of executives finding a job and $n_{i}$ the number of executives at risk (i.e., those who have not found a job or have not been censored) at time $t_{i}$.

As the influence of social performance of the previous employers is likely the strongest immediately after turnover, we focus on estimating the survivor function during the first five years after turnover. As the gap between employment is measured using years, and some executives find 
a new job in the same year of turnover. To ensure that the survival time is positive, we add one year to the actual duration of employment. In particular, when CEOs find another executive position in the same year of leaving the previous employer, the time to event is defined as one year (i.e., $t=1$ ). Similarly, an executive who found a new job five years after turnover is considered to have found a job by year six (i.e., $t=6$ ).

\section{[Insert Figure 1]}

Figure 1 Panel A presents two survival curves for executives from CSR firms and those from non-CSR firms. Since an event of finding a job is similar to death in traditional survival analysis, a higher survival rate at time $t$ means it takes longer for executives to find a job. The function of CSR executives is noticeable below that of non-CSR executives, indicating that the duration of unemployment is shorter for CSR executives. In particular, the risk of not finding the next executive position, in the same year of turnover is $92 \%$ for CSR firms, about $4 \%$ lower than that for non-CSR firms. The largest difference in the survival rate is observed at $\mathrm{t}=2$, (i.e., the risk of not finding an executive position by the end of the first year after turnover) - it is $62 \%$ for CSR firms, about $10 \%$ lower than that for non-CSR firms.

\section{[Insert Table 7]}

We next test for the equality of survivor functions between CSR firms and non-CSR firms in Panel A. Using both the log-rank test and the Wilcoxon test, we reject the null hypothesis that the two survivor functions are equal ( $p$-value $=0.047$ and 0.013 , respectively). Taken together with the visual comparison in Panel A, the results suggest that there is significant difference in the survivor functions between CSR firms and non-CSR firms.

In Panel B, we compare the survivor functions for CSR firms and non-CSR firms when an event is defined as finding an executive position in a public firm. Similar to the pattern in Panel A, 
the survival rate at any time $t$ is higher for CEOs from non-CSR firms than CSR firms, which suggests that it takes longer for CEOs leaving non-CSR firms than CSR firms to find another executive position in a public firm. The results from the log-rank test and Wilcoxon test reject the null hypothesis that the survivor functions for CSR and non-CSR firms are equal ( $p$-values $=0.024$ and 0.005 respectively). This lends statistical support to the visual difference between the two survivor functions. Although most departing CEOs do not find another executive position in a public firm, those leaving a CSR firm have a better chance. For example, at $t=2$, the survival rate for CEOs leaving a CSR firm is $89 \%, 6 \%$ lower than for those leaving a non-CSR firm, which suggests that it takes less time for CEOs leaving CSR firms to find an executive position in a public firm.

\subsubsection{Using a Semi-parametric model}

Next, we also employ the Cox proportional hazards (PH) model, a semi-parametric method, to account for the effect of other covariates affecting the occurrence and the speed of CEOs landing the next executive position. We are mainly interested in the coefficient on firms' CSR performance. A positive coefficient means that CEOs leaving firms with strong CSR performance can find another executive position faster than those leaving firms with weaker CSR performance.

In particular, let $T$ be the survival time, i.e., the number of years until a CEO finds another

executive position. The hazard function at time $t$ is defined as $h(t)=\lim _{\mathrm{k} \rightarrow 0} \frac{\operatorname{Pr}[t+k>T \geq t \mid T \geq t]}{k}$. The $\operatorname{Cox}$ PH model assumes that the hazard function $h(t)$ take the following expression,

$$
h(t)=h_{0}(t) \exp (\boldsymbol{X \beta})
$$

where $h_{0}(t)$ is the baseline hazards function that may be unspecified. The vector for covariates $\boldsymbol{X}$ include the same variables as in earlier models, including firm size, ROA, Return, the log of the 
executives' age, the log of their tenure, and restatement, all measured as of the last year that the executive holds the CEO position in the previous employer.

Panel A of Table 7 summarizes the estimation results from the Cox PH model. As in earlier tables, we define the indicator variable CSR Firm based on CSR performance over three different horizons, i.e., one year, two years and three years before the year of executive turnover. As expected, the coefficient on CSR FIRM is positive and significant across all three horizons. The hazard ratios reported along with the coefficients suggest that executives leaving CSR firms are about $26 \%$ to $30 \%$ more likely than those leaving non-CSR firms to find the next executive position. Similar to earlier regressions, the only two significant covariates are age and tenure-younger executives and those with shorter tenure are more likely to find a job.

In Panel B, we also report the estimation results from the Cox PH model where an event is defined as CEOs finding an executive position in a public firm. Regardless of the horizon over which we measure the CSR performance of the previous employer, the coefficient on CSR FIRM is positive and statistically significant $(0.4375,0.6035,0.6233$, all with $p$-values $<1 \%)$. The economic significance of the advantage of CSR executives in labor market is even more significant than in that in Panel A-executives from CSR firms are 55\%-86\% more likely than those from non-CSR firms to land an executive position in a public firm.

\subsection{Additional analysis}

\subsubsection{Moving up to a bigger public firm}

When we examine the probability of departing CEOs finding a new job, no distinction has been made as to the desirability of the next position except for whether it is at a public firm. Given the limited information we could gather from private firms in general, we now focus on executives 
who find an executive position in public firms after leaving their previous employers. Since public firms vary in size and working in larger firm is likely associated with prestige and higher compensation, we examine whether the CSR performance of the previous employer helps departing CEOs move up to work in a larger firm. To carry out the analysis, we restrict the sample to executives who subsequently find a job in a public firm, so the firm size of the previous employer and the future employer can be compared. A CEO is considered to be moving up if he/she lands a CEO position in a public firm that is in a higher firm size decile than his/her previous firm.

[Insert Table 8]

Table 8 presents the estimation of the likelihood of moving up to a large public firm. The first three columns show a positive and significant coefficient on CSR FIRM, which means that leaving a strong CSR-performing firm improves the chance of finding a CEO position in a larger firm. The difference in probability ranges from $19-22 \%$, and is likely economically significant. When we include the GENERAL ABILITY to control for managerial skills, which cuts the sample size further by more than $50 \%$. The effect of CSR FIRM on the likelihood of moving up remains positive and significant, ranging from $18-34 \%$. These results provide further support for our earlier results.

\subsubsection{Voluntary versus Forced Turnovers}

CEO turnovers can happen in very different circumstances. Some are forced turnovers due to unsatisfactory performance of various types, while others are voluntary turnovers. To gauge whether being CSR-conscious affects CEOs' job market outcomes differently for different types of turnovers, we merge our sample with the CEO turnover dataset developed by Jenter and Kanaan 
(2015), who categorize CEO turnovers into forced turnovers and voluntary turnovers. The requirement of non-missing data for the type of turnover reduces our sample by approximately $50 \%$. After identifying a voluntary turnover subsample and a forced turnover subsample, we rerun our analyses in these two subsamples separately. ${ }^{10}$

\section{[Insert Table 9]}

Panel A and panel B of Table 9 present results for the voluntary turnover subsample and the forced turnover subsample, respectively. CSR FIRM exhibits positive and significant relations with both favorable job market outcomes for the sample of voluntarily departing CEOs, despite the small sample size. In particular, leaving a CSR firm increases the chance of landing the next job or finding an executive position in a public firm by $10-12 \%$, and $8-10 \%$ respectively. On the other hand, when CEOs are forced to leave the firm, the coefficient estimates on CSR FIRM become insignificant across all specifications. This suggests that forced turnover is a signal of poor managerial skills, which is more important in shaping executives' future career path than the CSR performance of the previous employer.

\section{Conclusion}

Prior research suggests that potential employers use corporate financial performance as a signal of managerial ability when assessing external executive hires (Gilson, 1989; Houston and James, 1993; Cannella, Jr., Fraser, and Lee 1995; Fee and Hadlock 2003; Desai, Hogan, and Wilkins 2006). Recently, various stakeholders, including shareholders, have been increasingly

\footnotetext{
${ }^{10}$ It is worth noting that even though Jenter and Kanaan (2015) and this paper both studies CEO turnovers, our samples are rather different due to different research questions. While Jenter and Kanaan (2015) focus on the turnover itself, we study the future career outcomes, thus requiring the turnover CEO actually leave the original firm. Also, we do not include any departing CEO that is at or above 60 years old, which Jenter and Kanaan (2015) categorize as voluntary. In addition, our sample is constructed not only using Execucomp, but also using Boardx.
} 
using social performance as a performance metric (e.g., Dimson, Karakaş, and Li 2015). We examine whether and how the managerial labor market considers a firm's social performance in assessing managerial quality.

We examine the empirical question of whether a firm's social performance is related to the CEO's future job market opportunities by compiling a sample of CEO changes and manually collecting information about departing CEOs' subsequent employment records. We measure a firm's social performance with a summary CSR score that reflects various aspects of social responsibility using the social ratings data issued by MSCI. We find that CEOs leaving firms with strong social performance are more likely to secure new executive positions, after controlling for the size and financial performance of their previous employers and CEO characteristics such as age and tenure. We also find that CEOs leaving firms with strong CSR performance are more likely to be hired as executives by public firms. These results suggest that the managerial labor market rewards CEOs for their social performance. Our inference is robust to a number of alternative specifications, including measuring corporate social performance over different windows before CEO departures, using a conditional logit regression model, and controlling for general managerial ability. Our inference is also robust to using an instrumental variable approach to address the concern for endogeneity of CSR performance. Using a hazard model, we find that the employment gap is significantly shorter for CEOs leaving firms with strong social performance than for those from firms with weak social performance.

Focusing on the subsample of CEOs who secure new executive positions at publicly listed firms, we find that CEOs whose former employers have strong social performance are more likely to move to companies that are larger in size than their former employers. We also find that superior social performance rewards CEOs voluntarily leaving their previous employers but not CEOs who 
are forced to leave. Collectively, the results suggest that CEOs with a reputation of committing to social good have more favorable job market prospects. We contribute to the literature on managerial labor market by providing new evidence that potential employers consider corporate social performance, in addition to financial performance, as an indicator of managerial quality. 


\section{References}

Adams, Renée B., and Daniel Ferreira, 2009. Women in the boardroom and their impact on governance and performance. Journal of Financial Economics 94, 291-309.

Albuquerque, R., Durnev, A., \& Koskinen, Y., 2014. Corporate social responsibility and firm risk: Theory and empirical evidence. Working paper. Boston University.

Ashraf, Rasha, Rajesh Chakrabarti, Richard Fu, and Narayanan Jayaraman, 2010. Takeover immunity, takeovers, and the market for nonexecutive directors. Financial Management 39, 83-127.

Bénabou, R., Tirole, J., 2006. Incentives and Prosocial Behavior. The American Economic Review 96, 1652-1678.

Bénabou, R., Tirole, J., 2010. Individual and corporate social responsibility. Economica 77, 1-19.

Besley, T., Ghatak, M., 2007. Reforming public service delivery. Journal of African Economics $16,127-156$.

Cannella Jr., A. A., D. R. Fraser, D. S. Lee, 1995. Firm failure and managerial labor markets evidence from Texas banking. Journal of Financial Economics 38(2), 185-210.

Cheng, Ing-Haw and Hong, Harrison G. and Shue, Kelly, 2016. Do Managers Do Good with Other Peoples’ Money? Available at SSRN: https://ssrn.com/abstract=1962120

Cheng, B., Ioannis I., Serafeim, G. 2014. Corporate social responsibility and access to finance. Strategic Management Journal 35: 1-23.

Coles, Jeffrey L., and Chun Keung Hoi, 2003. New evidence on the market for directors: Board membership and Pennsylvania senate bill 1310. Journal of Finance 58, 197-230.

Custodio, C., Ferreira, M.A., and Matos, P., 2013. Generalists versus Specialists: Lifetime Work Experience and CEO Pay. Journal of Financial Economics 108(2), 471-492.

Derwall, Jeroen and Bauer, Rob and Guenster, Nadja and Koedijk, Kees C. G., 2005. The EcoEfficiency Premium Puzzle. Financial Analysts Journal, Vol. 61, No. 2, pp. 51-63, March/April 2005. Available at SSRN: https://ssrn.com/abstract=713861

Desai, H., Hogan, C., Wilkins, M., 2006. The Reputational Penalty for Aggressive Accounting: Earnings Restatements and Management Turnover. The Accounting Review 81: 83-112.

Dimson, E., Karakaş, O., and Li, X., 2015. Active ownership. Review of Financial Studies 28, 3225-3268. 
Dimson, E., Marsh, P. and Staunton, M., 2015. Responsible investing: Does it pay to be bad. Global Investment Returns Yearbook, pp.17-27.

Do, Nguyen, Rau. 2012. Sugar and spice and everything nice: what are good directors made of? SSRN working paper. https://papers.ssrn.com/sol3/papers.cfm?abstract id=2023087.

Dowell, G., Hart, S., Yeung, B., 2000. Do corporate global environmental standards create or destroy market value? Management Science 46, 1059-1074.

Edmans, Alex. 2011. Does the stock market fully value intangibles? Employee satisfaction and equity prices. Journal of Financial Economics 101: 621-640.

Edmans, Alex. 2012. The link between job satisfaction and firm value, with implications for corporate social responsibility. Academy of Management Perspectives 26, 1-19.

Ertimur, Y., Ferri, F., Stubben, S., 2010. Board of directors' responsiveness to shareholders: Evidence from shareholder proposals, Journal of Corporate Finance 16, 53-72.

Ertimur, Y., Rawson, C., Rogers, J. L., Zechman, S.L., 2017. Bridging the Gap: Evidence from externally hired CEOs. https://research.chicagobooth.edu/ /media/745350853ecf4a48ba6bbe2e322e4283.pdf

Falato, A., A. Li and T. Milbourn. 2012. CEO pay and the market for CEOs.

Fama, E., 1980. Agency problems and the theory of the firm. The Journal of Political Economy 88(2): 288-307.

Farrell, Kathleen A., and Philip L. Hersch, 2005. Additions to corporate boards: The effect of gender. Journal of Corporate Finance 11, 85-106.

Fee, C. Edward, and Charles J. Hadlock, 2003. Raids, rewards, and reputations in the market for managerial talent. Review of Financial Studies 16, 1315-1357.

Ferris, S. P., Murali Jagannathan, and A.C. Pritchard, 2003. Too busy to mind the business? Monitoring by directors with multiple board appointments. Journal of Finance 58, 1087-1111.

Fich, Eliezer M., and Lawrence J. White, 2005. Why do CEOs reciprocally sit on each other's boards? Journal of Corporate Finance 11, 175-195.

Fich, Eliezer M., and Anil Shivdasani, 2006. Are busy boards effective monitors? Journal of Finance 61, 689-724.

Flammer, Caroline. 2015. Does Corporate Social Responsibility Lead to Superior Financial Performance? A Regression Discontinuity Approach. Management Science 61(11):2549-2568. 
Friedman, M., 1970. The social responsibility of business is to increase its profits. The New York Times Magazine, September 13, 1970.

Gao, F., Lisic, L.L. and Zhang, I.X., 2014. Commitment to social good and insider trading. Journal of Accounting and Economics, 57(2): 149-175.

Gilson, S. C., 1989. Management Turnover and Financial Distress. Journal of Financial Economics 25, 241-262.

Glac, K., 2014. The influence of shareholders on corporate social responsibility, Ethics and Business Law Faculty Publications 66. http://ir.stthomas.edu/ocbeblpub/66

Greene, W., 2004. The behavior of the maximum likelihood estimator of limited dependent variable models in the presence of fixed effects. Econometrics Journal 7: 98-119.

Grossman, Blake R. and William F. Sharpe. 1986. Financial Implications of South African Divestment. Financial Analysts Journal 42, 15-29.

Groysberg, B., 2014. The sever skills you need to thrive in the C-Suite. Harvard Business Review. 3/18/2014. 2-6.

Gul, Ferdinand A., Bin Srinidhi, and Anthony C. Ng, 2011. Does board gender diversity improve the informativeness of stock prices? Journal of Accounting and Economics 51, 314-338.

Harford, J. and Schonlau, R.J., 2013. Does the director labor market offer ex post settling-up for CEOs? The case of acquisitions. Journal of Financial Economics 110, 18-36.

Hart, O., Zingales, L., 2017. Companies should maximize shareholder welfare not market value. Journal of Law, Finance, and Accounting 2, 247-274.

Hirshleifer, D., Thakor, A.V., 1992. Managerial conservatism, project choice and debt. The Review of Financial Studies 5, 437-470.

Holmström, B., Ricart I Costa, J., 1986. Managerial Incentives and Capital Management. The Quarterly Journal of Economics 101 (1), 835-860.

Holmström, B. 1999. Managerial Incentive Problems: A Dynamic Perspective. The Review of Economic Studies 66 (1), 169-182.

Hong, H., Kubik, J.D., Scheinkman, J.A., 2012. Financial constraints on corporate goodness. http://econ.columbia.edu/files/econ/financial_constraints_on_corporate_goodness.pdf.

Hong, H., Kacperczyk, M., 2009. The price of sin: The effects of social norms on markets. Journal of Financial Economics 93, 15-36. 
Houston, Joel F. and Christopher James, 1993. Management and organizational changes in banking: A comparison of regulatory intervention with private creditor auctions in nonbank firms. Carnegie-Rochester Conference Series on Public Policy 38, 143-178.

Jensen, M.C., Meckling, W.H., 1976. Theory of the firm: Managerial behavior, agency costs and ownership structure. Journal of Financial Economics 3, 305-360.

Jenter, D. and Kanaan, F., 2015. CEO turnover and relative performance evaluation. The Journal of Finance, 70(5), 2155-2184.

Kim, J. B., Shroff, P., Vyas, D., and Wittenberg-Moerman, R. 2018. Credit Default Swaps and Managers' Voluntary Disclosure. Journal of Accounting Research 56, 953-988. Accepted Author Manuscript. doi:10.1111/1475-679X.12194

Kruger, P., 2015. Corporate goodness and shareholder wealth. Journal of Financial Economics $115,304-329$.

Masulis, R.W., Reza, S.W., 2015. Agency problems of corporate philanthropy. Review of Financial Studies 28, 592-636.

Marshall, Cassandra D., 2010. Are dissenting directors rewarded? Working paper. Available at SSRN: https://ssrn.com/abstract=1668642 or http://dx.doi.org/10.2139/ssrn.1668642

Milbourn, T. T. 2003. CEO reputation and stock-based compensation. Journal of Financial Economics 68, 233-262.

Meyer, B. Unemployment insurance and unemployment spells. Econometrica 58: 757-782.

Pigou, A. C., 1920. The economics of welfare. http://oll.libertyfund.org/EBooks/Pigou_0316.pdf.

Rajgopal, S., T. Shevlin and V. Zamora. 2006. CEOs' outside employment opportunities and the lack of relative performance evaluation in compensation contracts. Journal of Finance 61, 1813-1844.

Servaes, H., Tamayo, A.M., 2013. The impact of corporate social responsibility on firm value: the role of customer awareness. Management Science 59, 1045-1061.

Scharfstein, D.S., Stein, J.C., 1990. Herd behavior and investment. The American Economic Review 80, 465-479.

Turban, D., Greening, D.W., 1997. Corporate social performance and organizational attractiveness to prospective employees. The Academy of Management Journal 40, 658-672.

Welsh, H., and T. Smith. 2011. Proxy season 2011: A tipping point for social and environmental issues? The Harvard Law School Forum on Corporate Governance and Financial Regulation, 18 September. 
$\mathrm{Wu}, \mathrm{Y} ., 2004$. The impact of public opinion on board structure changes, director career progression, and CEO turnover: Evidence from CalPERS' corporate governance program, Journal of Corporate Finance 10, 199-227. 


\section{Appendix: Variable Definitions}

\begin{tabular}{|c|c|}
\hline Variable & Definition \\
\hline \multicolumn{2}{|c|}{ Job Market Consequences } \\
\hline New job & $\begin{array}{l}\text { A dummy variable that equals one if a CEO finds a new job after } \\
\text { turnover, and zero otherwise. }\end{array}$ \\
\hline Public job & $\begin{array}{l}\text { A dummy variable that equals one if a CEO finds a new job in a public } \\
\text { firm after turnover, and zero otherwise. }\end{array}$ \\
\hline Move up & $\begin{array}{l}\text { A dummy variable that equals one if a CEO finds a CEO position at } \\
\text { a firm that is in a higher total asset decile, and zero otherwise. }\end{array}$ \\
\hline
\end{tabular}

CSR Related Variables

CSR score

The difference between the number of strengths and concerns measured over a period, such as one year, two years or three years prior to last year of turnover.

CSR FIRM

A dummy variable that equals one if a firm's CSR score (i.e., the difference between the number of strengths and concerns measured over a period) is positive, and zero otherwise.

Adj. CSR FIRM

A dummy variable that equals one if a firm's adjusted CSR score is positive, and zero otherwise. Following Servaes and Tamayo (2013), we deflate the number of strengths or concerns by the maximum possible number of strengths or concerns in a CSR category for each firm-year.

IndCSR Average CSR score of other firms in the same industry at the year of a CEO's turnover.

\section{Other Control Variables}

SIZE

ROA

RET

AGE

TENURE

RESTATE

GENERAL ABILITY
The market capitalization of the previous employer.

Average industry adjusted ROA over a particular measuring horizon. Average industry adjusted return over a particular measuring horizon. CEO's age as turnover year in the previous employer CEO's tenure length in the previous employer as of turnover year A dummy variable if there is a restatement in a CEO's tenure in the previous employer.

General ability index, the first factor extracted from a principal components analysis to five proxies of general managerial ability: past number of positions, number of firms, number of industries, CEO experience dummy, and conglomerate experience dummy (BoardEx). 
Figure 1. The length of time before getting a positive job market outcome

This figures describes the duration of unemployment before a positive job market outcome for executives leaving the previous company. Positive outcomes include finding an executive position, and finding an executive position in a public company within 5 years after turnover. We use CSR score measured over the previous year (i.e., CSR horizon=1 year) to classify whether a firm is CSR concious or not. The graphs for other horizons are similar but untabulated.

\section{Panel A. Duration of unemployment}

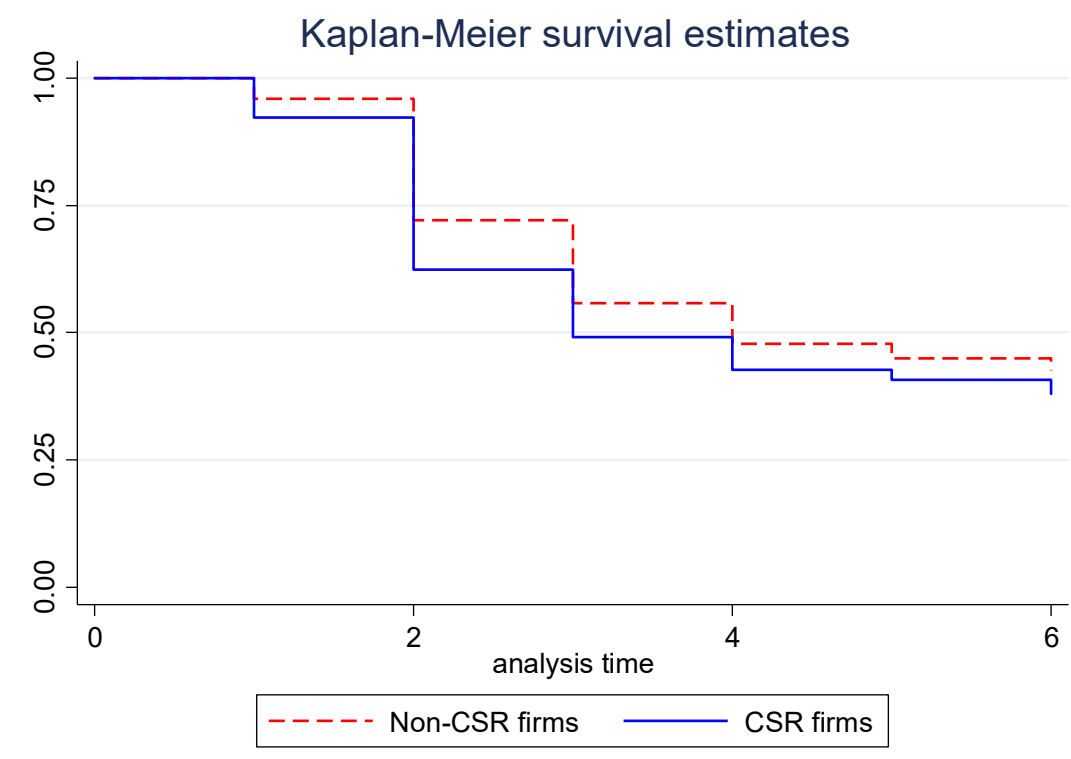

Panel B. Duration before finding an executive position in a public firm.

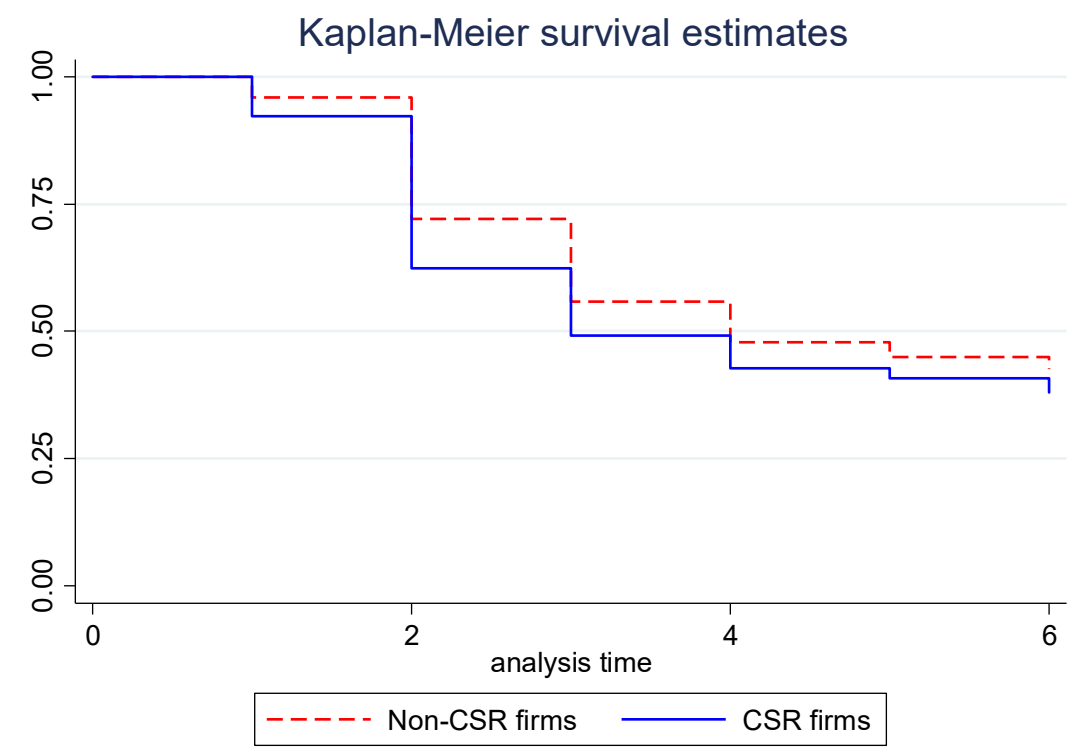


Table 1

\section{Executive Turnover Sample Distribution}

This table presents the sample distributions. Panel A reports the distribution of CEO turnovers by year. Panel B reports the industry distribution of CEO turnovers sample. Panel C presents departing CEOs' age distribution. Panel D summarizes the categories of departing CEOs' new jobs.

Panel A Sample Distribution by Turnover Year

\begin{tabular}{ccc}
\hline Turnover Year & Frequency & Percent \\
\hline 1993 & 3 & 0.16 \\
1994 & 19 & 0.99 \\
1995 & 23 & 1.2 \\
1996 & 28 & 1.46 \\
1997 & 26 & 1.36 \\
1998 & 32 & 1.67 \\
1999 & 35 & 1.83 \\
2000 & 52 & 2.72 \\
2001 & 81 & 4.23 \\
2002 & 90 & 4.7 \\
2003 & 131 & 6.84 \\
2004 & 169 & 8.83 \\
2005 & 197 & 10.29 \\
2006 & 186 & 9.71 \\
2007 & 227 & 11.85 \\
2008 & 163 & 8.51 \\
2009 & 126 & 6.58 \\
2010 & 145 & 7.57 \\
2011 & 139 & 7.26 \\
2012 & 43 & 2.25 \\
\hline Total & 1915 & 100 \\
\hline & &
\end{tabular}


Panel B Sample Distribution by Industry

\begin{tabular}{|c|c|c|c|}
\hline FF12 & Industry & Frequency & Percent \\
\hline 1 & Consumer NonDurable & 88 & 4.6 \\
\hline 2 & Consumer Durables & 40 & 2.09 \\
\hline 3 & Manufacturing & 145 & 7.57 \\
\hline 4 & Oil, Gas, and Coal Extraction and Products & 60 & 3.13 \\
\hline 5 & Chemicals and Allied Products & 32 & 1.67 \\
\hline 6 & Business Equipment & 467 & 24.39 \\
\hline 7 & Telephone and Television Transmission & 38 & 1.98 \\
\hline 8 & Utilities & 48 & 2.51 \\
\hline 9 & Wholesale, Retail, and Some Services & 208 & 10.86 \\
\hline 10 & Healthcare, Medical Equipment, and Drugs & 272 & 14.2 \\
\hline 11 & Finance & 281 & 14.67 \\
\hline \multirow[t]{2}{*}{12} & Other & 236 & 12.32 \\
\hline & Total & 1915 & 100 \\
\hline
\end{tabular}

\section{Panel C Executive Age Distribution at Turnover}

\begin{tabular}{lcc}
\hline AGE at Turnover & Frequency & Percent \\
\hline $35<=\mathrm{AGE}<=39$ & 74 & 3.86 \\
$40<=\mathrm{AGE}<=44$ & 202 & 10.55 \\
$45<=\mathrm{AGE}<=49$ & 377 & 19.69 \\
$50<=\mathrm{AGE}<=54$ & 626 & 32.69 \\
$55<=\mathrm{AGE}<=59$ & 636 & 33.21 \\
\hline Total & 1915 & 100.00 \\
\hline
\end{tabular}

Panel D Distribution of New Firm Types

\begin{tabular}{lcc}
\hline New Firm Type & Frequency & Percent \\
\hline Public & 281 & 14.67 \\
Private & 944 & 49.30 \\
Nonprofit & 20 & 1.04 \\
Others & 17 & 0.88 \\
No New Job & 653 & 34.10 \\
\hline Total & 1915 & 100 \\
\hline
\end{tabular}


Table 2

Descriptive Statistics

This table reports descriptive statistics of the sample with CEO turnover. In panel A, we summarize the explanatory variables used in our analysis, all of which are the characteristics of the previous employer. Panel B compares the characteristics of the previous employer for departing CEOs, partitioned by whether a firm is a CSR conscious firm or not, using its CSR performance based on the most recent year. Panel C exhibits executives' subsequent employment categories by most recent year's CSR performance. CSR FIRM is a dummy variable that equals one if a firm's CSR score is positive over the one year, two years, and three years measuring window. SIZE is the market capitalization. ROA is the average industry adjusted ROA over the measuring window. RET is the average industry adjusted return over the measuring window. $A G E$ is the CEO's age at turnover. TENURE is the CEO's tenure length as the original firms' CEO. RESTATE is a dummy variable if there is a restatement in a CEO's tenure.

Panel A. Characteristics of the Previous Employer

\begin{tabular}{lcccccc}
\hline Variable & N & Mean & Std Dev & 25th Pctl & Median & 75th Pctl \\
\hline CSR FIRM & & & & & & \\
CSR Horizon=1 year & 1006 & 0.2932 & 0.4555 & 0 & 0 & 1 \\
CSR Horizon-2 years & 1113 & 0.2938 & 0.4557 & 0 & 0 & 1 \\
CSR Horizon=3 years & 1139 & 0.2994 & 0.4582 & 0 & 0 & 1 \\
SIZE & 1900 & 2892.32 & 11540.42 & 92.0798 & 336.0023 & 1350.06 \\
ROA & 1898 & -0.0985 & 0.3051 & -0.1367 & 0.0014 & 0.0471 \\
RET & 1797 & -0.0068 & 0.0512 & -0.0334 & -0.0030 & 0.0210 \\
AGE & 1915 & 51.1128 & 5.6225 & 47 & 52 & 56 \\
TENURE & 1915 & 6.3666 & 4.2380 & 3 & 5 & 8 \\
RESTATE & 1915 & 0.0240 & 0.1532 & 0 & 0 & 0 \\
\hline
\end{tabular}

Panel B. Characteristics of the Previous Employer, Partitioned by Whether a Firm Is a CSR FIRM in the Year Prior to Turnover (CSR horizon $=1$ year)

\begin{tabular}{|c|c|c|c|c|c|c|c|c|}
\hline \multirow[b]{2}{*}{ Variable } & \multicolumn{3}{|c|}{ Non CSR FIRMs } & \multicolumn{3}{|c|}{ CSR FIRMs } & \multirow[b]{2}{*}{ Difference } & \multirow[b]{2}{*}{$\operatorname{Pr}>|t|$} \\
\hline & $\mathrm{N}$ & Mean & Std Dev & $\mathrm{N}$ & Mean & Std Dev & & \\
\hline SIZE & 711 & 2762.97 & 10445.87 & 295 & 10047.60 & 22605.51 & 7284.63 & $<.0001$ \\
\hline ROA & 709 & -0.0481 & 0.2499 & 295 & -0.0093 & 0.1771 & 0.0388 & 0.0055 \\
\hline RET & 689 & -0.0032 & 0.0484 & 284 & -0.0039 & 0.0449 & -0.0007 & 0.8302 \\
\hline AGE & 711 & 51.6399 & 5.4284 & 295 & 52.5322 & 4.5399 & 0.8923 & 0.0077 \\
\hline TENURE & 711 & 6.5781 & 4.3604 & 295 & 6.4678 & 3.8009 & -0.1103 & 0.6888 \\
\hline RESTATE & 711 & 0.0225 & 0.1484 & 295 & 0.0339 & 0.1813 & 0.0114 & 0.3401 \\
\hline
\end{tabular}


Panel C. Distribution of New Firm Types by CSR Performance in the Year Prior to Turnover (i.e., CSR horizon = 1 year)

\begin{tabular}{lccc}
\hline & \multicolumn{3}{c}{ CSR performance of the previous employer } \\
\cline { 2 - 4 } New Firm Type & CSR FIRMs & Non-CSR FIRMs & Total \\
\hline Public & 58 & 98 & 156 \\
Private & 135 & 331 & 466 \\
Nonprofit & 2 & 8 & 10 \\
Others & 4 & 5 & 9 \\
No New Job & 96 & 269 & 365 \\
\hline Total & 295 & 711 & 1006 \\
\hline
\end{tabular}


Table 3

Probability of Finding a Job

This table tests the relationship between CSR performance and a favorable job market outcome-finding a new job. Specifically, we run the following regression:

$$
\begin{aligned}
\text { New job }= & \alpha_{0}+\beta_{1} \text { CSRFIRM } M_{t}+\beta 2 \log (\text { SIZE })+\beta_{3} R O A+\beta_{4} R E T+\beta 5 \log (A G E)+\beta 6 \log (\text { TENURE }) \\
& +\beta_{7} \text { RESTATE }+ \text { Year FE }+ \text { Industry FE }+\varepsilon_{i, t}
\end{aligned}
$$

where $N e w$ job is a dummy variable that equals one if a CEO finds a new job after turnover, and zero otherwise. CSR FIRM is a dummy variable that equals one if a firm's CSR score is positive over the one year, two years, or three years measuring window. SIZE is the market capitalization. ROA is the average industry adjusted ROA over the measuring window. RET is the average industry adjusted return over the measuring window. $A G E$ is the CEO's age at turnover. TENURE is the CEO's tenure length as the original firms' CEO. RESTATE is a dummy variable if there is a restatement in a CEO's tenure. Heteroscedasticityrobust standard errors are estimated and clustered at the industry level. Industry and year fixed effects are included in all regressions. Standard errors are reported in parentheses. $*, * *$, and $* * *$ denote statistical

\begin{tabular}{|c|c|c|c|}
\hline \multirow[t]{2}{*}{ CSR Horizon } & 1 Year & 2 Years & 3 Years \\
\hline & $\begin{array}{l}\text { Coeff. } \\
(\mathrm{SE})\end{array}$ & $\begin{array}{l}\text { Coeff. } \\
\text { (SE) }\end{array}$ & $\begin{array}{l}\text { Coeff. } \\
\text { (SE) }\end{array}$ \\
\hline CSR FIRM & $\begin{array}{l}0.0711 * * \\
(0.0302)\end{array}$ & $\begin{array}{l}0.0833 * * * \\
(0.0249)\end{array}$ & $\begin{array}{l}0.0721 * * * \\
(0.0178)\end{array}$ \\
\hline $\log (\mathrm{SIZE})$ & $\begin{array}{l}-0.0007 \\
(0.0056)\end{array}$ & $\begin{array}{l}-0.0038 \\
(0.0058)\end{array}$ & $\begin{array}{l}-0.0025 \\
(0.0057)\end{array}$ \\
\hline ROA & $\begin{array}{l}0.0038 * * \\
(0.0014)\end{array}$ & $\begin{array}{l}0.0044 * * \\
(0.0017)\end{array}$ & $\begin{array}{l}0.0064 * * \\
(0.0026)\end{array}$ \\
\hline RET & $\begin{array}{l}0.1423 \\
(0.3541)\end{array}$ & $\begin{array}{l}0.5257 \\
(0.4867)\end{array}$ & $\begin{array}{l}0.4377 \\
(0.4771)\end{array}$ \\
\hline $\log (\mathrm{AGE})$ & $\begin{array}{l}-1.2852 * * * \\
(0.1424)\end{array}$ & $\begin{array}{l}-1.2830 * * * \\
(0.1257)\end{array}$ & $\begin{array}{l}-1.2843^{* * *} \\
(0.1205)\end{array}$ \\
\hline Log(TENURE) & $\begin{array}{l}-0.0750 * * * \\
(0.0196)\end{array}$ & $\begin{array}{l}-0.0779 * * * \\
(0.0210)\end{array}$ & $\begin{array}{l}-0.0770^{* * *} \\
(0.0215)\end{array}$ \\
\hline RESTATE & $\begin{array}{l}-0.0010 \\
(0.0557)\end{array}$ & $\begin{array}{l}-0.0129 \\
(0.0523)\end{array}$ & $\begin{array}{l}-0.0202 \\
(0.0565)\end{array}$ \\
\hline Industry FE & Included & Included & Included \\
\hline Year FE & Included & Included & Included \\
\hline Adjusted $\mathrm{R}^{2}$ & 0.1567 & 0.1582 & 0.1598 \\
\hline $\mathrm{N}$ & 972 & 1072 & 1093 \\
\hline
\end{tabular}
significance at the $10 \%, 5 \%$, and $1 \%$ levels. 
Table 4

Probability of finding a job in a public firm

This table tests the relationship between CSR performance and a favorable job market outcome-finding an executive position in a public firm. Specifically, we run the following regression:

$$
\begin{aligned}
\text { Public job } & =\alpha_{0}+\beta_{1} \text { CSRFIRM } M_{t}+\beta 2 \log (\text { SIZE })+\beta_{3} R O A+\beta_{4} R E T+\beta 5 \log (A G E)+\beta 6 \log (\text { TENURE }) \\
& +\beta_{7} \text { RESTATE }+ \text { Year FE }+ \text { Industry FE }+\varepsilon_{i, t}
\end{aligned}
$$

where Public job is a dummy variable that equals one if a CEO finds a new job in a public firm after turnover, and zero otherwise. CSR FIRM is a dummy variable that equals one if a firm's CSR score is positive over the one year, two years, or three years measuring window. SIZE is the market capitalization. $R O A$ is the average industry adjusted ROA over the measuring window. RET is the average industry adjusted return over the measuring window. $A G E$ is the CEO's age at turnover. TENURE is the CEO's tenure length as the original firms' CEO. RESTATE is a dummy variable if there is a restatement in a CEO's tenure. Heteroscedasticity-robust standard errors are estimated and clustered at the industry level. Industry and year fixed effects are included in all regressions. Standard errors are reported in parentheses. *, **, and

\begin{tabular}{|c|c|c|c|}
\hline \multirow[t]{2}{*}{ CSR Horizon } & 1 Year & 2 Years & 3 Years \\
\hline & $\begin{array}{l}\text { Coeff. } \\
\text { (SE) }\end{array}$ & $\begin{array}{l}\text { Coeff. } \\
\text { (SE) }\end{array}$ & $\begin{array}{l}\text { Coeff. } \\
\text { (SE) }\end{array}$ \\
\hline CSR FIRM & $\begin{array}{l}0.0417 * * \\
(0.0195)\end{array}$ & $\begin{array}{l}0.0624 * * * \\
(0.0175)\end{array}$ & $\begin{array}{l}0.0669 * * * \\
(0.0150)\end{array}$ \\
\hline $\log ($ SIZE $)$ & $\begin{array}{l}-0.0031 \\
(0.0086)\end{array}$ & $\begin{array}{l}-0.0066 \\
(0.0081)\end{array}$ & $\begin{array}{l}-0.0048 \\
(0.0067)\end{array}$ \\
\hline ROA & $\begin{array}{l}-0.0003 \\
(0.0012)\end{array}$ & $\begin{array}{l}-0.0019 \\
(0.0013)\end{array}$ & $\begin{array}{l}-0.0015 \\
(0.0019)\end{array}$ \\
\hline RET & $\begin{array}{l}0.3947 \\
(0.2999)\end{array}$ & $\begin{array}{l}0.5171 \\
(0.3721)\end{array}$ & $\begin{array}{l}0.2561 \\
(0.2199)\end{array}$ \\
\hline $\log (A G E)$ & $\begin{array}{l}-0.1755^{*} \\
(0.0884)\end{array}$ & $\begin{array}{l}-0.1864 * * \\
(0.0802)\end{array}$ & $\begin{array}{l}-0.1802 * \\
(0.0849)\end{array}$ \\
\hline Log(TENURE) & $\begin{array}{l}-0.0627 * * \\
(0.0203)\end{array}$ & $\begin{array}{l}-0.0677 * * * \\
(0.0164)\end{array}$ & $\begin{array}{l}-0.0668^{* * *} \\
(0.0171)\end{array}$ \\
\hline RESTATE & $\begin{array}{l}0.1013 \\
(0.0892)\end{array}$ & $\begin{array}{l}0.0834 \\
(0.0838)\end{array}$ & $\begin{array}{l}0.0824 \\
(0.0848)\end{array}$ \\
\hline Industry FE & Included & Included & Included \\
\hline Year FE & Included & Included & Included \\
\hline Adjusted $\mathrm{R}^{2}$ & 0.0256 & 0.0287 & 0.0282 \\
\hline $\mathrm{N}$ & 972 & 1072 & 1093 \\
\hline
\end{tabular}
*** denote statistical significance at the $10 \%, 5 \%$, and $1 \%$ levels. 
Table 5

\section{Robustness Checks}

This table presents robustness tests for results found in table 3 and table 4. Panel A and panel B reports robustness checks using CSR Score and Adj. CSR FIRM as alternative measures for CSR FIRM, respectively. Panel C presents tests using five years and the whole tenure period as alternative measuring horizons of CSR FIRM, ROA, and RET. Panel D reports results using a conditional logit regression method. Panel E reports the regression results controlling for general managerial ability. CSR Score is the difference between the number of strengths and concerns measured over the one year, two years, or three years measuring window. Adj. CSR FIRM is a dummy variable that equals one if a firm's adjusted CSR score is positive over the one year, two years or three years measuring window. SIZE is the market capitalization. ROA is the average industry adjusted ROA over the measuring window. RET is the average industry adjusted return over the measuring window. $A G E$ is the CEO's age at turnover. TENURE is the CEO's tenure length as the original firms' CEO. RESTATE is a dummy variable if there is a restatement in a CEO's tenure. GENERAL ABILITY is the general managerial ability index in Custodio et al. (2013). Heteroscedasticity-robust standard errors are estimated and clustered at the industry level. Industry and year fixed effects are included in all regressions. Standard errors are reported in parentheses. ${ }^{*}, * *$, and $* * *$ denote statistical significance at the $10 \%, 5 \%$, and $1 \%$ levels.

Panel A. Using CSR Score as an alternative measure for CSR Performance

\begin{tabular}{|c|c|c|c|c|c|c|}
\hline \multirow{2}{*}{$\begin{array}{l}\text { Dependent variable } \\
\text { CSR Horizons }\end{array}$} & \multicolumn{3}{|c|}{ Prob(Finding a new job) } & \multicolumn{3}{|c|}{ Prob(Finding a job in a public firm) } \\
\hline & 1 Year & 2 Years & 3 Years & 1 Year & 2 Years & 3 Years \\
\hline & $\begin{array}{l}\text { Coeff. } \\
{[\mathrm{SE}]}\end{array}$ & $\begin{array}{l}\text { Coeff. } \\
{[\mathrm{SE}]}\end{array}$ & $\begin{array}{l}\text { Coeff. } \\
{[\mathrm{SE}]}\end{array}$ & $\begin{array}{l}\text { Coeff. } \\
{[\mathrm{SE}]}\end{array}$ & $\begin{array}{l}\text { Coeff. } \\
{[\mathrm{SE}]}\end{array}$ & $\begin{array}{l}\text { Coeff. } \\
{[\mathrm{SE}]}\end{array}$ \\
\hline CSR Score & $\begin{array}{l}0.0169 * * \\
{[0.0070]}\end{array}$ & $\begin{array}{l}0.0152 * * \\
{[0.0058]}\end{array}$ & $\begin{array}{l}0.0143^{* * *} \\
{[0.0051]}\end{array}$ & $\begin{array}{l}0.0132 * * * \\
{[0.0039]}\end{array}$ & $\begin{array}{l}0.0152 * * * \\
{[0.0033]}\end{array}$ & $\begin{array}{l}0.0164 * * * \\
{[0.0034]}\end{array}$ \\
\hline $\log (\mathrm{SIZE})$ & $\begin{array}{l}-0.0037 \\
{[0.0052]}\end{array}$ & $\begin{array}{l}-0.0038 \\
{[0.0053]}\end{array}$ & $\begin{array}{l}-0.0022 \\
{[0.0058]}\end{array}$ & $\begin{array}{l}-0.0066 \\
{[0.0079]}\end{array}$ & $\begin{array}{l}-0.0083 \\
{[0.0076]}\end{array}$ & $\begin{array}{l}-0.0059 \\
{[0.0064]}\end{array}$ \\
\hline ROA & $\begin{array}{l}0.0037 * * \\
{[0.0015]}\end{array}$ & $\begin{array}{l}0.0041 * * \\
{[0.0018]}\end{array}$ & $\begin{array}{l}0.0062 * * \\
{[0.0024]}\end{array}$ & $\begin{array}{l}-0.0004 \\
{[0.0012]}\end{array}$ & $\begin{array}{l}-0.0022 \\
{[0.0014]}\end{array}$ & $\begin{array}{l}-0.0017 \\
{[0.0020]}\end{array}$ \\
\hline RET & $\begin{array}{l}0.1659 \\
{[0.3500]}\end{array}$ & $\begin{array}{l}0.5314 \\
{[0.4595]}\end{array}$ & $\begin{array}{l}0.4451 \\
{[0.4595]}\end{array}$ & $\begin{array}{l}0.4192 \\
{[0.2931]}\end{array}$ & $\begin{array}{l}0.5488 \\
{[0.3793]}\end{array}$ & $\begin{array}{l}0.2837 \\
{[0.2401]}\end{array}$ \\
\hline $\log (\mathrm{AGE})$ & $\begin{array}{l}-1.2857 * * * \\
{[0.1463]}\end{array}$ & $\begin{array}{l}-1.2808 * * * \\
{[0.1247]}\end{array}$ & $\begin{array}{l}-1.2848 * * * \\
{[0.1204]}\end{array}$ & $\begin{array}{l}-0.1794 * \\
{[0.0856]}\end{array}$ & $\begin{array}{l}-0.1888 * * \\
{[0.0793]}\end{array}$ & $\begin{array}{l}-0.1838 * \\
{[0.0843]}\end{array}$ \\
\hline Log(TENURE) & $\begin{array}{l}-0.0754 * * * \\
{[0.0204]}\end{array}$ & $\begin{array}{l}-0.0781 * * * \\
{[0.0215]}\end{array}$ & $\begin{array}{l}-0.0757 * * * \\
{[0.0218]}\end{array}$ & $\begin{array}{l}-0.0630 * * \\
{[0.0208]}\end{array}$ & $\begin{array}{l}-0.0677 * * * \\
{[0.0167]}\end{array}$ & $\begin{array}{l}-0.0656^{* * *} \\
{[0.0171]}\end{array}$ \\
\hline
\end{tabular}




\begin{tabular}{lllllll} 
RESTATE & -0.0013 & -0.0134 & -0.0166 & 0.0999 & 0.0826 & 0.0853 \\
& {$[0.0541]$} & {$[0.0532]$} & {$[0.0576]$} & {$[0.0872]$} & {$[0.0807]$} & {$[0.0822]$} \\
Industry FE & Included & Included & Included & Included & Included & Included \\
Year FE & Included & Included & Included & Included & Included & Included \\
& & & & & & \\
Adjusted $\mathrm{R}^{2}$ & 0.1573 & 0.1559 & 0.1582 & 0.0283 & 0.0290 & 0.0277 \\
$\mathrm{~N}$ & 972 & 1072 & 1093 & 972 & 1072 & 1093 \\
\hline
\end{tabular}


Panel B. Using $A d j$. CSR FIRM as an alternative measure for CSR performance

\begin{tabular}{|c|c|c|c|c|c|c|}
\hline \multirow{2}{*}{$\begin{array}{l}\text { Dependent variable } \\
\text { CSR Horizon }\end{array}$} & \multicolumn{3}{|c|}{ Prob(Finding a new job) } & \multicolumn{3}{|c|}{ Prob(Finding a job in a public firm) } \\
\hline & 1 Year & 2 Years & 3 Years & 1 Year & 2 Years & 3 Years \\
\hline & $\begin{array}{l}\text { Coeff. } \\
{[\mathrm{SE}]}\end{array}$ & $\begin{array}{l}\text { Coeff. } \\
{[\mathrm{SE}]}\end{array}$ & $\begin{array}{l}\text { Coeff. } \\
{[\mathrm{SE}]}\end{array}$ & $\begin{array}{l}\text { Coeff. } \\
{[\mathrm{SE}]}\end{array}$ & $\begin{array}{l}\text { Coeff. } \\
{[\mathrm{SE}]}\end{array}$ & $\begin{array}{l}\text { Coeff. } \\
{[\mathrm{SE}]}\end{array}$ \\
\hline \multirow[t]{2}{*}{ Adj. CSR FIRM } & $0.0790 * * *$ & $0.0861 * * *$ & $0.0793^{* * *}$ & $0.0529 * *$ & $0.0593 * * *$ & $0.0619 * * *$ \\
\hline & [0.0289] & {$[0.0287]$} & {$[0.0251]$} & {$[0.0182]$} & {$[0.0175]$} & {$[0.0196]$} \\
\hline \multirow[t]{2}{*}{$\log (\mathrm{SIZE})$} & -0.0002 & -0.0025 & -0.0014 & -0.0033 & -0.0052 & -0.0031 \\
\hline & {$[0.0050]$} & {$[0.0051]$} & {$[0.0050]$} & {$[0.0078]$} & {$[0.0070]$} & {$[0.0061]$} \\
\hline \multirow[t]{2}{*}{ ROA } & $0.0038 * *$ & $0.0042 * *$ & $0.0062 * *$ & -0.0004 & -0.0020 & -0.0016 \\
\hline & {$[0.0014]$} & {$[0.0018]$} & {$[0.0026]$} & {$[0.0012]$} & {$[0.0014]$} & {$[0.0019]$} \\
\hline \multirow[t]{2}{*}{ RET } & 0.1322 & 0.4794 & 0.3804 & 0.3907 & 0.4788 & 0.1988 \\
\hline & {$[0.3547]$} & {$[0.4822]$} & {$[0.4768]$} & {$[0.2959]$} & {$[0.3652]$} & {$[0.2216]$} \\
\hline \multirow[t]{2}{*}{$\log (\mathrm{AGE})$} & $-1.2857 * * *$ & $-1.2814 * * *$ & $-1.2841 * * *$ & $-0.1774 *$ & $-0.1842 * *$ & $-0.1780^{*}$ \\
\hline & [0.1418] & {$[0.1261]$} & [0.1223] & {$[0.0884]$} & [0.0829] & {$[0.0862]$} \\
\hline \multirow[t]{2}{*}{ Log(TENURE) } & $-0.0758 * * *$ & $-0.0787 * * *$ & $-0.0761 * * *$ & $-0.0633 * *$ & $-0.0683 * * *$ & $-0.0660 * * *$ \\
\hline & {$[0.0196]$} & [0.0207] & {$[0.0216]$} & {$[0.0206]$} & {$[0.0163]$} & {$[0.0170]$} \\
\hline \multirow[t]{2}{*}{ RESTATE } & 0.0047 & -0.0104 & -0.0167 & 0.1046 & 0.0852 & 0.0859 \\
\hline & {$[0.0562]$} & {$[0.0539]$} & {$[0.0572]$} & {$[0.0885]$} & {$[0.0826]$} & {$[0.0830]$} \\
\hline Industry FE & Included & Included & Included & Included & Included & Included \\
\hline Year FE & Included & Included & Included & Included & Included & Included \\
\hline Adjusted $\mathrm{R}^{2}$ & 0.1575 & 0.1582 & 0.1604 & 0.0271 & 0.0278 & 0.0268 \\
\hline $\mathrm{N}$ & 972 & 1072 & 1093 & 972 & 1072 & 1093 \\
\hline
\end{tabular}


Panel C. Alternative measuring horizons for CSR

\begin{tabular}{|c|c|c|c|c|}
\hline \multirow{2}{*}{$\begin{array}{l}\text { Dependent variable } \\
\text { CSR Horizon }\end{array}$} & \multicolumn{2}{|c|}{ Prob(Finding a new job) } & \multicolumn{2}{|c|}{ Prob(Finding a job in a public firm) } \\
\hline & 5 Years & Over the Tenure & 5 Years & Over the Tenure \\
\hline & $\begin{array}{l}\text { Coeff. } \\
(\mathrm{SE})\end{array}$ & $\begin{array}{l}\text { Coeff. } \\
(\mathrm{SE})\end{array}$ & $\begin{array}{c}\text { Coeff. } \\
(\mathrm{SE})\end{array}$ & $\begin{array}{l}\text { Coeff. } \\
(\mathrm{SE})\end{array}$ \\
\hline CSR FIRM & $\begin{array}{c}0.0567 * * \\
(0.0221)\end{array}$ & $\begin{array}{l}0.0450 * * \\
(0.0172)\end{array}$ & $\begin{array}{c}0.0494 * * * \\
(0.0158)\end{array}$ & $\begin{array}{c}0.0494 * * * \\
(0.0147)\end{array}$ \\
\hline $\log (\mathrm{SIZE})$ & $\begin{array}{c}0.0009 \\
(0.0050)\end{array}$ & $\begin{array}{c}0.0010 \\
(0.0055)\end{array}$ & $\begin{array}{l}-0.0048 \\
(0.0070)\end{array}$ & $\begin{array}{l}-0.0050 \\
(0.0066)\end{array}$ \\
\hline ROA & $\begin{array}{c}0.0101 * * * \\
(0.0026)\end{array}$ & $\begin{array}{l}0.0092 * * \\
(0.0037)\end{array}$ & $\begin{array}{l}-0.0013 \\
(0.0025)\end{array}$ & $\begin{array}{l}-0.0012 \\
(0.0026)\end{array}$ \\
\hline RET & $\begin{array}{c}0.4301 \\
(0.5905)\end{array}$ & $\begin{array}{c}0.4099 \\
(0.5826)\end{array}$ & $\begin{array}{c}0.1511 \\
(0.3363)\end{array}$ & $\begin{array}{c}0.2069 \\
(0.3570)\end{array}$ \\
\hline $\log (\mathrm{AGE})$ & $\begin{array}{c}-1.2817 * * * \\
(0.1172)\end{array}$ & $\begin{array}{c}-1.2815^{* * *} \\
(0.1188)\end{array}$ & $\begin{array}{l}-0.1773 * \\
(0.0894)\end{array}$ & $\begin{array}{l}-0.1777^{*} \\
(0.0874)\end{array}$ \\
\hline Log(TENURE) & $\begin{array}{c}-0.0781 * * * \\
(0.0210)\end{array}$ & $\begin{array}{c}-0.0752 * * * \\
(0.0227)\end{array}$ & $\begin{array}{c}-0.0648 * * * \\
(0.0149)\end{array}$ & $\begin{array}{c}-0.0664 * * * \\
(0.0149)\end{array}$ \\
\hline RESTATE & $\begin{array}{l}-0.0111 \\
(0.0573)\end{array}$ & $\begin{array}{l}-0.0101 \\
(0.0570)\end{array}$ & $\begin{array}{c}0.0827 \\
(0.0838)\end{array}$ & $\begin{array}{c}0.0834 \\
(0.0837)\end{array}$ \\
\hline Industry FE & Included & Included & Included & Included \\
\hline Year FE & Included & Included & Included & Included \\
\hline Adjusted $\mathrm{R}^{2}$ & 0.1579 & 0.1553 & 0.0241 & 0.0244 \\
\hline $\mathrm{N}$ & 1114 & 1116 & 1114 & 1116 \\
\hline
\end{tabular}


Panel D. Conditional Logit Regressions

\begin{tabular}{|c|c|c|c|c|c|c|}
\hline \multirow{2}{*}{$\begin{array}{l}\text { Dependent variable } \\
\text { CSR Horizon }\end{array}$} & \multicolumn{3}{|c|}{ Prob(Finding a new job) } & \multicolumn{3}{|c|}{ Prob(Finding a job in a public firm) } \\
\hline & 1 Year & 2 Years & 3 Years & 1 Year & 2 Years & 3 Years \\
\hline & $\begin{array}{l}\text { Coeff. } \\
{[\mathrm{SE}]}\end{array}$ & $\begin{array}{l}\text { Coeff. } \\
{[\mathrm{SE}]}\end{array}$ & $\begin{array}{l}\text { Coeff. } \\
{[\mathrm{SE}]}\end{array}$ & $\begin{array}{l}\text { Coeff. } \\
{[\mathrm{SE}]}\end{array}$ & $\begin{array}{l}\text { Coeff. } \\
{[\mathrm{SE}]}\end{array}$ & $\begin{array}{l}\text { Coeff. } \\
{[\mathrm{SE}]}\end{array}$ \\
\hline \multirow[t]{2}{*}{ CSR FIRM } & $0.4206^{* * *}$ & $0.4919^{* * *}$ & $0.4518 * * *$ & $0.3959^{* * *}$ & $0.5496^{* * *}$ & $0.6075 * * *$ \\
\hline & {$[0.1648]$} & {$[0.1512]$} & [0.1089] & {$[0.1643]$} & {$[0.1559]$} & {$[0.1220]$} \\
\hline \multirow[t]{2}{*}{$\log ($ SIZE $)$} & 0.0384 & 0.0153 & 0.0210 & 0.0227 & -0.0019 & 0.0074 \\
\hline & {$[0.0370]$} & {$[0.0315]$} & {$[0.0285]$} & {$[0.0575]$} & {$[0.0612]$} & {$[0.0538]$} \\
\hline \multirow[t]{2}{*}{ ROA } & 0.0111 & 0.0145 & 0.0211 & -0.0069 & $-0.0228^{*}$ & -0.0199 \\
\hline & {$[0.0078]$} & {$[0.0091]$} & {$[0.0147]$} & {$[0.0121]$} & {$[0.0129]$} & {$[0.0165]$} \\
\hline \multirow[t]{2}{*}{ RET } & 0.9982 & 3.2148 & 3.2411 & 3.0600 & 3.4388 & 1.6883 \\
\hline & {$[1.5070]$} & [2.3629] & [2.1784] & {$[2.5280]$} & [3.3909] & [1.8989] \\
\hline \multirow[t]{2}{*}{$\log (\mathrm{AGE})$} & $-6.8970 * * *$ & $-7.0120 * * *$ & $-7.0854 * * *$ & $-1.6253^{* *}$ & $-1.7046^{* *}$ & $-1.6538 * *$ \\
\hline & [1.1232] & {$[0.9828]$} & [0.9595] & [0.7974] & {$[0.6778]$} & {$[0.7184]$} \\
\hline \multirow[t]{2}{*}{ Log(TENURE) } & $-0.3089 * * *$ & $-0.3514 * * *$ & $-0.3567 * * *$ & $-0.5461 * * *$ & $-0.6199 * * *$ & $-0.6153 * * *$ \\
\hline & {$[0.0847]$} & {$[0.0888]$} & {$[0.0956]$} & [0.1589] & {$[0.1321]$} & {$[0.1376]$} \\
\hline \multirow[t]{2}{*}{ RESTATE } & -0.0588 & -0.1259 & -0.1564 & 0.6451 & 0.5437 & 0.5193 \\
\hline & {$[0.2804]$} & {$[0.2570]$} & {$[0.2691]$} & {$[0.5110]$} & {$[0.5256]$} & {$[0.5254]$} \\
\hline Ind FE & Included & Included & Included & Included & Included & Included \\
\hline Adjusted $\mathrm{R}^{2}$ & 0.0832 & 0.0903 & 0.0905 & 0.0315 & 0.0395 & 0.0389 \\
\hline $\mathrm{N}$ & 972 & 1072 & 1093 & 972 & 1072 & 1093 \\
\hline
\end{tabular}


Panel E. Controlling for Managers' General Ability

\begin{tabular}{|c|c|c|c|c|c|c|}
\hline \multirow{2}{*}{$\begin{array}{l}\text { Dependent variable } \\
\text { CSR Horizon }\end{array}$} & \multicolumn{3}{|c|}{ Prob(Finding a new job) } & \multicolumn{3}{|c|}{ Prob(Finding a job in a public firm) } \\
\hline & 1 Year & 2 Years & 3 Years & 1 Year & 2 Years & 3 Years \\
\hline & $\begin{array}{l}\text { Coeff. } \\
(\mathrm{SE})\end{array}$ & $\begin{array}{l}\text { Coeff. } \\
(\mathrm{SE})\end{array}$ & $\begin{array}{l}\text { Coeff. } \\
(\mathrm{SE})\end{array}$ & $\begin{array}{l}\text { Coeff. } \\
(\mathrm{SE})\end{array}$ & $\begin{array}{l}\text { Coeff. } \\
\text { (SE) }\end{array}$ & $\begin{array}{l}\text { Coeff. } \\
(\mathrm{SE})\end{array}$ \\
\hline CSR FIRM & $\begin{array}{l}0.0810 * * \\
(0.0323)\end{array}$ & $\begin{array}{l}0.1047 * * * \\
(0.0220)\end{array}$ & $\begin{array}{l}0.1111^{* * *} \\
(0.0278)\end{array}$ & $\begin{array}{l}0.0380 \\
(0.0471)\end{array}$ & $\begin{array}{l}0.0676^{*} \\
(0.0409)\end{array}$ & $\begin{array}{l}0.0782 * * * \\
(0.0249)\end{array}$ \\
\hline GENERAL ABILITY & $\begin{array}{l}0.0993 * * * \\
(0.0269)\end{array}$ & $\begin{array}{l}0.0888 * * \\
(0.0298)\end{array}$ & $\begin{array}{l}0.0909 * * \\
(0.0323)\end{array}$ & $\begin{array}{l}0.0604 * * \\
(0.0210)\end{array}$ & $\begin{array}{l}0.0580 * * \\
(0.0200)\end{array}$ & $\begin{array}{l}0.0560 * * \\
(0.0187)\end{array}$ \\
\hline $\log (\mathrm{SIZE})$ & $\begin{array}{l}0.0131 \\
(0.0286)\end{array}$ & $\begin{array}{l}0.0151 \\
(0.0243)\end{array}$ & $\begin{array}{l}0.0199 \\
(0.0242)\end{array}$ & $\begin{array}{l}-0.0190 * \\
(0.0101)\end{array}$ & $\begin{array}{l}-0.0194 * * \\
(0.0077)\end{array}$ & $\begin{array}{l}-0.0183 * * \\
(0.0065)\end{array}$ \\
\hline ROA & $\begin{array}{l}-0.0022 \\
(0.0060)\end{array}$ & $\begin{array}{l}0.0031 \\
(0.0054)\end{array}$ & $\begin{array}{l}0.0030 \\
(0.0069)\end{array}$ & $\begin{array}{l}-0.0082 * * \\
(0.0036)\end{array}$ & $\begin{array}{l}-0.0079 * * \\
(0.0033)\end{array}$ & $\begin{array}{l}-0.0048 \\
(0.0032)\end{array}$ \\
\hline RET & $\begin{array}{l}0.7344 \\
(0.8562)\end{array}$ & $\begin{array}{l}0.5890 \\
(0.8786)\end{array}$ & $\begin{array}{l}0.9098 \\
(1.3527)\end{array}$ & $\begin{array}{l}1.4599 * \\
(0.7041)\end{array}$ & $\begin{array}{l}1.5069 * \\
(0.8003)\end{array}$ & $\begin{array}{l}1.5719 \\
(0.9207)\end{array}$ \\
\hline $\log (\mathrm{AGE})$ & $\begin{array}{l}-1.7602 * * * \\
(0.1586)\end{array}$ & $\begin{array}{l}-1.7454 * * * \\
(0.1222)\end{array}$ & $\begin{array}{l}-1.7354 * * * \\
(0.1372)\end{array}$ & $\begin{array}{l}-0.4955^{*} \\
(0.2394)\end{array}$ & $\begin{array}{l}-0.5008^{*} \\
(0.2741)\end{array}$ & $\begin{array}{l}-0.4990 * \\
(0.2754)\end{array}$ \\
\hline $\log ($ TENURE $)$ & $\begin{array}{l}-0.0665 \\
(0.0536)\end{array}$ & $\begin{array}{l}-0.0752 \\
(0.0553)\end{array}$ & $\begin{array}{l}-0.0806 \\
(0.0561)\end{array}$ & $\begin{array}{l}-0.0061 \\
(0.0313)\end{array}$ & $\begin{array}{l}-0.0132 \\
(0.0296)\end{array}$ & $\begin{array}{l}-0.0135 \\
(0.0293)\end{array}$ \\
\hline RESTATE & $\begin{array}{l}-0.0904 \\
(0.1508)\end{array}$ & $\begin{array}{l}-0.0897 \\
(0.1549)\end{array}$ & $\begin{array}{l}-0.0916 \\
(0.1574)\end{array}$ & $\begin{array}{l}0.0367 \\
(0.1041)\end{array}$ & $\begin{array}{l}0.0305 \\
(0.1104)\end{array}$ & $\begin{array}{l}0.0329 \\
(0.1116)\end{array}$ \\
\hline Industry FE & Included & Included & Included & Included & Included & Included \\
\hline Year FE & Included & Included & Included & Included & Included & Included \\
\hline Adjusted $\mathrm{R}^{2}$ & 0.2531 & 0.2581 & 0.2614 & 0.0832 & 0.0816 & 0.0757 \\
\hline $\mathrm{N}$ & 349 & 361 & 363 & 349 & 361 & 363 \\
\hline
\end{tabular}


Table 6

\section{Instrumental Variables}

This table presents estimates of 2SLS regressions of executives' job market outcomes, New job and Public $j o b$, on CSR performance of the previous employer (CSR FIRM), with average industry CSR performance $($ IndCSR) as an instrumental variable. Panel A and panel B reports the first stage and second stage results, respectively. New job is a dummy variable that equals one if a $\mathrm{CEO}$ finds a new job after turnover, and zero otherwise. Public job is a dummy variable that equals one if a CEO finds a new job in a public firm after turnover, and zero otherwise. CSR FIRM is a dummy variable that equals one if a firm's CSR score is positive over the one year, two years, or three years measuring window. IndCSR is the average CSR score of other firms in the same industry at the year of a CEO's turnover. SIZE is the market capitalization. ROA is the average industry adjusted ROA over the measuring window. RET is the average industry adjusted return over the measuring window. $A G E$ is the CEO's age at turnover. TENURE is the CEO's tenure length as the original firms' CEO. RESTATE is a dummy variable if there is a restatement in a CEO's tenure. Heteroscedasticity-robust standard errors are estimated and clustered at the industry level. Standard errors are reported in parentheses. ${ }^{*}, * *$, and $* * *$ denote statistical significance at the $10 \%, 5 \%$, and $1 \%$ levels.

\begin{tabular}{|c|c|c|c|}
\hline \multicolumn{4}{|c|}{ Panel A. First Stage } \\
\hline \multirow[t]{2}{*}{ CSR Horizon } & 1 Year & 2 Years & 3 Years \\
\hline & $\begin{array}{l}\text { Coeff. } \\
(\mathrm{SE})\end{array}$ & $\begin{array}{l}\text { Coeff. } \\
\text { (SE) }\end{array}$ & $\begin{array}{l}\text { Coeff. } \\
(\mathrm{SE})\end{array}$ \\
\hline \multirow[t]{2}{*}{ Industry CSR } & $0.0765 * * *$ & $0.0612 * * *$ & $0.0751 * * *$ \\
\hline & $(0.0204)$ & $(0.0190)$ & $(0.0227)$ \\
\hline \multirow[t]{2}{*}{$\log (\mathrm{SIZE})$} & $0.0871 * * *$ & $0.0888 * * *$ & $0.0842 * * *$ \\
\hline & $(0.0122)$ & $(0.0105)$ & $(0.0096)$ \\
\hline \multirow[t]{2}{*}{ ROA } & -0.0027 & -0.0027 & 0.0008 \\
\hline & $(0.0026)$ & $(0.0027)$ & $(0.0025)$ \\
\hline \multirow[t]{2}{*}{ RET } & -0.5060 & $-1.2975^{* * *}$ & $-1.2956 * *$ \\
\hline & $(0.3532)$ & $(0.4452)$ & $(0.5087)$ \\
\hline \multirow[t]{2}{*}{$\log (\mathrm{AGE})$} & $0.2934 * *$ & $0.2437 *$ & $0.2175^{*}$ \\
\hline & $(0.1232)$ & $(0.1233)$ & $(0.1105)$ \\
\hline \multirow[t]{2}{*}{ Log(TENURE) } & -0.0032 & -0.0094 & 0.0116 \\
\hline & $(0.0259)$ & $(0.0251)$ & $(0.0230)$ \\
\hline \multirow[t]{2}{*}{ RESTATE } & 0.0879 & 0.0207 & 0.0783 \\
\hline & $(0.0805)$ & $(0.0743)$ & $(0.0914)$ \\
\hline Industry FE & Included & Included & Included \\
\hline Year FE & Included & Included & Included \\
\hline F-test: IndCSR $=0$ & 14.1 & 10.42 & 10.94 \\
\hline $\mathrm{N}$ & 959 & 1059 & 1080 \\
\hline
\end{tabular}


Panel B. Second Stage

\begin{tabular}{|c|c|c|c|c|c|c|}
\hline \multirow{2}{*}{$\begin{array}{l}\text { Dependent } \\
\text { CSR Horizon }\end{array}$} & \multicolumn{3}{|c|}{ Prob(Finding a new job) } & \multicolumn{3}{|c|}{ Prob(Finding a job in a public firm) } \\
\hline & 1 Year & 2 Years & 3 Years & 1 Year & 2 Years & 3 Years \\
\hline & $\begin{array}{l}\text { Coeff. } \\
(\mathrm{SE})\end{array}$ & $\begin{array}{l}\text { Coeff. } \\
(\mathrm{SE})\end{array}$ & $\begin{array}{l}\text { Coeff. } \\
(\mathrm{SE})\end{array}$ & $\begin{array}{l}\text { Coeff. } \\
(\mathrm{SE})\end{array}$ & $\begin{array}{l}\text { Coeff. } \\
(\mathrm{SE})\end{array}$ & $\begin{array}{l}\text { Coeff. } \\
(\mathrm{SE})\end{array}$ \\
\hline \multirow[t]{2}{*}{ CSR FIRM } & $0.6366 * *$ & $0.7855 * *$ & $0.5636^{*}$ & $0.8422 * * *$ & $0.9881 * * *$ & $0.7517 * * *$ \\
\hline & $(0.3748)$ & $(0.4597)$ & $(0.3644)$ & $(0.3447)$ & $(0.4208)$ & $(0.3218)$ \\
\hline \multirow[t]{2}{*}{$\log (\mathrm{SIZE})$} & -0.0516 & $-0.0672 *$ & -0.0450 & $-0.0714 * *$ & $-0.0869 * *$ & $-0.0608 * *$ \\
\hline & $(0.0325)$ & $(0.0405)$ & $(0.0310)$ & $(0.0328)$ & $(0.0368)$ & $(0.0251)$ \\
\hline \multirow[t]{2}{*}{$\mathrm{ROA}$} & $0.0051 * *$ & $0.0062 * *$ & 0.0059 & 0.0015 & 0.0006 & -0.0019 \\
\hline & $(0.0020)$ & $(0.0028)$ & $(0.0041)$ & $(0.0021)$ & $(0.0026)$ & $(0.0022)$ \\
\hline \multirow[t]{2}{*}{ RET } & 0.4381 & $1.4578 * *$ & $1.1054^{*}$ & $0.7697^{*}$ & $1.6786 * * *$ & $1.0899 * *$ \\
\hline & $(0.4530)$ & $(0.7387)$ & $(0.6425)$ & $(0.4534)$ & $(0.6476)$ & $(0.5138)$ \\
\hline \multirow[t]{2}{*}{$\log (\mathrm{AGE})$} & $-1.4695 * * *$ & $-1.4689 * * *$ & $-1.4075 * * *$ & $-0.4123 * *$ & $-0.4131 * *$ & $-0.3329 * *$ \\
\hline & $(0.1554)$ & $(0.1748)$ & $(0.1505)$ & $(0.1603)$ & $(0.1610)$ & $(0.1448)$ \\
\hline \multirow[t]{2}{*}{ Log(TENURE) } & $-0.0751 * * *$ & $-0.0736 * * *$ & $-0.0845 * * *$ & $-0.0621 * * *$ & $-0.0608 * *$ & $-0.0759 * * *$ \\
\hline & $(0.0233)$ & $(0.0260)$ & $(0.0250)$ & $(0.0221)$ & $(0.0264)$ & $(0.0220)$ \\
\hline \multirow[t]{2}{*}{ RESTATE } & -0.0443 & -0.0215 & -0.0539 & 0.0363 & 0.0688 & 0.0324 \\
\hline & $(0.0864)$ & $(0.0708)$ & $(0.0748)$ & $(0.1102)$ & $(0.0978)$ & $(0.0946)$ \\
\hline Industry FE & Included & Included & Included & Included & Included & Included \\
\hline Year FE & Included & Included & Included & Included & Included & Included \\
\hline $\mathrm{N}$ & 959 & 1059 & 1080 & 959 & 1059 & 1080 \\
\hline
\end{tabular}




\section{Table 7 Duration analysis using the COX Proportional Hazards Model}

This table presents estimates of the COX PH model for the relation between the chance of finding an executive position (in Panel A) or finding an executive position (in Panel B) within five years of leaving the previous employer and covariates. CSR FIRM is a dummy variable that equals one if a firm's CSR score is positive over the one year, two years, or three years measuring window. SIZE is the market capitalization. $R O A$ is the average industry adjusted ROA over the measuring window. $R E T$ is the average industry adjusted return over the measuring window. $A G E$ is the CEO's age at turnover. TENURE is the CEO's tenure length as the original firms' CEO. RESTATE is a dummy variable if there is a restatement in a CEO's tenure. Standard errors are reported in parentheses. ${ }^{*}, * *$, and $* * *$ denote statistical significance at the $10 \%, 5 \%$, and $1 \%$ levels.

\section{Panel A. Chance of finding a new executive position}

\begin{tabular}{|c|c|c|c|c|c|c|}
\hline \multirow[t]{2}{*}{ CSR Horizon } & \multicolumn{2}{|l|}{1 Year } & \multicolumn{2}{|l|}{2 Years } & \multicolumn{2}{|l|}{3 Years } \\
\hline & $\begin{array}{l}\text { Coeff } \\
(\mathrm{SE})\end{array}$ & Hazard Ratio & $\begin{array}{l}\text { Coeff } \\
(\mathrm{SE})\end{array}$ & Hazard Ratio & $\begin{array}{l}\text { Coeff } \\
(\mathrm{SE})\end{array}$ & Hazard Ratio \\
\hline \multirow[t]{2}{*}{ CSR FIRM } & $0.2273 * * *$ & 1.26 & $0.2582 * * *$ & 1.29 & $0.2633 * * *$ & 1.30 \\
\hline & $(0.0958)$ & & $(0.0958)$ & & $(0.0977)$ & \\
\hline \multirow[t]{2}{*}{$\log (\mathrm{SIZE})$} & 0.0144 & 1.01 & 0.0027 & 1.00 & 0.0009 & 1.00 \\
\hline & $(0.0287)$ & & $(0.0266)$ & & $(0.0258)$ & \\
\hline \multirow[t]{2}{*}{$\mathrm{ROA}$} & 0.0051 & 1.01 & 0.0059 & 1.01 & 0.0104 & 1.01 \\
\hline & $(0.0069)$ & & $(0.0073)$ & & $(0.0087)$ & \\
\hline \multirow[t]{2}{*}{ RET } & 0.5906 & 1.81 & 1.5172 & 4.56 & 0.7581 & 2.13 \\
\hline & (1.0909) & & (1.3974) & & $(1.5008)$ & \\
\hline \multirow[t]{2}{*}{$\log (\mathrm{AGE})$} & $-3.0635 * * *$ & 0.05 & $-3.0754 * * *$ & 0.05 & $-3.0599 * * *$ & 0.05 \\
\hline & $(0.3643)$ & & $(0.3449)$ & & $(0.3411)$ & \\
\hline \multirow[t]{2}{*}{ Log(TENURE) } & $-0.2032 * * *$ & 0.82 & $-0.2173 * * *$ & 0.80 & $-0.2147 * * *$ & 0.81 \\
\hline & $(0.0645)$ & & $(0.0612)$ & & $(0.0608)$ & \\
\hline \multirow[t]{2}{*}{ RESTATE } & -0.1836 & 0.83 & -0.1808 & 0.83 & -0.1852 & 0.83 \\
\hline & $(0.2630)$ & & $(0.2540)$ & 1.29 & $(0.2540)$ & \\
\hline Chi-square & 87.144 & & 102.339 & & 103.509 & \\
\hline $\mathrm{N}$ & 972 & & 1072 & & 1093 & \\
\hline
\end{tabular}


Panel B. Chance of finding an executive position in a public firm

\begin{tabular}{|c|c|c|c|c|c|c|}
\hline \multirow[t]{2}{*}{ CSR Horizon } & \multicolumn{2}{|l|}{1 Year } & \multicolumn{2}{|l|}{2 Years } & \multicolumn{2}{|l|}{3 Years } \\
\hline & $\begin{array}{l}\text { Coeff } \\
\text { (SE) }\end{array}$ & Hazard Ratio & $\begin{array}{l}\text { Coeff } \\
\text { (SE) }\end{array}$ & Hazard Ratio & $\begin{array}{l}\text { Coeff } \\
\text { (SE) }\end{array}$ & Hazard Ratio \\
\hline CSR FIRM & $\begin{array}{l}0.4375^{* * *} \\
(0.1953)\end{array}$ & 1.55 & $\begin{array}{l}0.6035^{* * *} \\
(0.1928)\end{array}$ & 1.83 & $\begin{array}{l}0.6223 * * * \\
(0.1969)\end{array}$ & 1.86 \\
\hline $\log (\mathrm{SIZE})$ & $\begin{array}{l}0.0169 \\
(0.0599)\end{array}$ & 1.02 & $\begin{array}{l}-0.0134 \\
(0.0557)\end{array}$ & 0.99 & $\begin{array}{l}-0.0027 \\
(0.0541)\end{array}$ & 1.00 \\
\hline ROA & $\begin{array}{l}-0.0009 \\
(0.0163)\end{array}$ & 1.00 & $\begin{array}{l}-0.0134 \\
(0.0186)\end{array}$ & 0.99 & $\begin{array}{l}-0.0093 \\
(0.0211)\end{array}$ & 0.99 \\
\hline RET & $\begin{array}{l}3.2541 \\
(2.3157)\end{array}$ & 25.90 & $\begin{array}{l}3.7251 \\
(2.9587)\end{array}$ & 41.47 & $\begin{array}{l}1.2136 \\
(3.2183)\end{array}$ & 3.37 \\
\hline $\log (\mathrm{AGE})$ & $\begin{array}{l}-2.4426 * * * \\
(0.8146)\end{array}$ & 0.09 & $\begin{array}{l}-2.5463 * * * \\
(0.7703)\end{array}$ & 0.08 & $\begin{array}{l}-2.5219 * * * \\
(0.7664)\end{array}$ & 0.08 \\
\hline Log(TENURE) & $\begin{array}{l}-0.5188^{* * *} \\
(0.1397)\end{array}$ & 0.60 & $\begin{array}{l}-0.5625^{* * *} \\
(0.1334)\end{array}$ & 0.57 & $\begin{array}{l}-0.5551 * * * \\
(0.1334)\end{array}$ & 0.57 \\
\hline RESTATE & $\begin{array}{l}0.3591 \\
(0.4226)\end{array}$ & 1.43 & $\begin{array}{l}0.3080 \\
(0.4202)\end{array}$ & 1.36 & $\begin{array}{l}0.3028 \\
(0.4203)\end{array}$ & 1.35 \\
\hline Chi-square & 33.863 & & 44.270 & & 42.444 & \\
\hline $\mathrm{N}$ & 972 & & 1072 & & 1093 & \\
\hline
\end{tabular}


Table 8

Move up within Public placements

This table presents the estimation of the likelihood of finding a CEO position in a larger public firm within five years of leaving the previous employer, conditional on finding a job in a public firm. The dependent variable is Move up, a dummy variable that equals one if a CEO finds a CEO position at a firm that is in a higher total asset decile, and zero otherwise. CSR FIRM is a dummy variable that equals one if a firm's CSR score is positive over the one year, two years, or three years measuring window. SIZE is the market capitalization. ROA is the average industry adjusted ROA over the measuring window. RET is the average industry adjusted return over the measuring window. $A G E$ is the CEO's age at turnover. TENURE is the CEO's tenure length as the original firms' CEO. RESTATE is a dummy variable if there is a restatement in a CEO's tenure. Heteroscedasticity-robust standard errors are estimated and clustered at the industry level. Industry and year fixed effects are included in all regressions. Standard errors are reported in parentheses. $* * *$, and $* * *$ denote statistical significance at the $10 \%, 5 \%$, and $1 \%$ levels.

\begin{tabular}{|c|c|c|c|c|c|c|}
\hline \multirow[t]{2}{*}{ CSR Horizon } & 1 Year & 2 Years & 3 Years & 1 Year & 2 Years & 3 Years \\
\hline & $\begin{array}{l}\text { Coeff. } \\
(\mathrm{SE})\end{array}$ & $\begin{array}{l}\text { Coeff. } \\
\text { (SE) }\end{array}$ & $\begin{array}{l}\text { Coeff. } \\
(\mathrm{SE})\end{array}$ & $\begin{array}{l}\text { Coeff. } \\
\text { (SE) }\end{array}$ & $\begin{array}{l}\text { Coeff. } \\
\text { (SE) }\end{array}$ & $\begin{array}{l}\text { Coeff. } \\
(\mathrm{SE})\end{array}$ \\
\hline CSR FIRM & $\begin{array}{l}0.2239 * * \\
(0.1013)\end{array}$ & $\begin{array}{l}0.2143 * * * \\
(0.0759)\end{array}$ & $\begin{array}{l}0.1858 * * * \\
(0.0552)\end{array}$ & $\begin{array}{l}0.2432 * * \\
(0.1122)\end{array}$ & $\begin{array}{l}0.3264 * * * \\
(0.1055)\end{array}$ & $\begin{array}{l}0.1806^{* *} \\
(0.0902)\end{array}$ \\
\hline GENERAL ABILITY INDEX & & & & $\begin{array}{l}0.0689 \\
(0.1067)\end{array}$ & $\begin{array}{l}0.0344 \\
(0.1273)\end{array}$ & $\begin{array}{l}0.0528 \\
(0.1019)\end{array}$ \\
\hline $\log ($ SIZE $)$ & $\begin{array}{l}-0.0075 \\
(0.0271)\end{array}$ & $\begin{array}{l}-0.0057 \\
(0.0225)\end{array}$ & $\begin{array}{l}-0.0071 \\
(0.0234)\end{array}$ & $\begin{array}{l}0.0102 \\
(0.1015)\end{array}$ & $\begin{array}{l}-0.0114 \\
(0.0756)\end{array}$ & $\begin{array}{l}0.0068 \\
(0.0795)\end{array}$ \\
\hline ROA & $\begin{array}{l}-0.0092 * * \\
(0.0030)\end{array}$ & $\begin{array}{l}-0.0074 \\
(0.0054)\end{array}$ & $\begin{array}{l}-0.0099 \\
(0.0077)\end{array}$ & $\begin{array}{l}-0.0532 * \\
(0.0241)\end{array}$ & $\begin{array}{l}-0.0480 * * * \\
(0.0076)\end{array}$ & $\begin{array}{l}-0.0494 * * \\
(0.0159)\end{array}$ \\
\hline RET & $\begin{array}{l}0.9428 \\
(0.7676)\end{array}$ & $\begin{array}{l}2.0594 * \\
(1.0707)\end{array}$ & $\begin{array}{l}3.0929 * * \\
(1.2616)\end{array}$ & $\begin{array}{l}-2.5946 \\
(1.9969)\end{array}$ & $\begin{array}{l}0.2772 \\
(1.7190)\end{array}$ & $\begin{array}{l}5.3347 * * \\
(2.1843)\end{array}$ \\
\hline $\log (\mathrm{AGE})$ & $\begin{array}{l}0.4470 \\
(0.4706)\end{array}$ & $\begin{array}{l}0.1997 \\
(0.4419)\end{array}$ & $\begin{array}{l}0.2973 \\
(0.4019)\end{array}$ & $\begin{array}{l}1.0775 \\
(0.7056)\end{array}$ & $\begin{array}{l}0.5897 \\
(0.4522)\end{array}$ & $\begin{array}{l}0.6959 * \\
(0.3338)\end{array}$ \\
\hline $\log ($ TENURE) & $\begin{array}{l}-0.1116^{*} \\
(0.0578)\end{array}$ & $\begin{array}{l}-0.1177 * * \\
(0.0534)\end{array}$ & $\begin{array}{l}-0.1241^{* *} \\
(0.0539)\end{array}$ & $\begin{array}{l}-0.1186 \\
(0.0742)\end{array}$ & $\begin{array}{l}-0.0903 \\
(0.0976)\end{array}$ & $\begin{array}{l}-0.0882 \\
(0.0928)\end{array}$ \\
\hline RESTATE & $\begin{array}{l}0.0218 \\
(0.2347)\end{array}$ & $\begin{array}{l}-0.0512 \\
(0.2070)\end{array}$ & $\begin{array}{l}-0.0786 \\
(0.1859)\end{array}$ & $\begin{array}{l}0.4183 * * * \\
(0.1247)\end{array}$ & $\begin{array}{l}0.2145^{* *} \\
(0.0822)\end{array}$ & $\begin{array}{l}0.0586 \\
(0.1899)\end{array}$ \\
\hline
\end{tabular}




\begin{tabular}{lllllll}
$\begin{array}{l}\text { Industry FE } \\
\text { Year FE }\end{array}$ & $\begin{array}{l}\text { Included } \\
\text { Included }\end{array}$ & $\begin{array}{l}\text { Included } \\
\text { Included }\end{array}$ & $\begin{array}{l}\text { Included } \\
\text { Included }\end{array}$ & $\begin{array}{l}\text { Included } \\
\text { Included }\end{array}$ & $\begin{array}{l}\text { Included } \\
\text { Included }\end{array}$ & $\begin{array}{l}\text { Included } \\
\text { Included }\end{array}$ \\
Adjusted $\mathrm{R}^{2}$ & 0.0843 & 0.0599 & 0.0466 & 0.2335 & 0.1804 & 0.1874 \\
$\mathrm{~N}$ & 151 & 168 & 170 & 68 & 71 & 71 \\
\hline
\end{tabular}


Table 9

Forced and Voluntary Turnover Subsample Tests

Panel A and panel B of Table 9 present results for the voluntary turnover subsample and the forced turnover subsample, respectively. New job is a dummy variable that equals one if a CEO finds a new job after turnover, and zero otherwise. Public job is a dummy variable that equals one if a CEO finds a new job in a public firm after turnover, and zero otherwise. CSR FIRM is a dummy variable that equals one if a firm's CSR score is positive over the one year, two years, or three years measuring window. SIZE is the market capitalization. ROA is the average industry adjusted ROA over the measuring window. RET is the average industry adjusted return over the measuring window. $A G E$ is the CEO's age at turnover. TENURE is the CEO's tenure length as the original firms' CEO. RESTATE is a dummy variable if there is a restatement in a CEO's tenure. Heteroscedasticity-robust standard errors are estimated and clustered at the industry level. Industry and year fixed effects are included in all regressions. Standard errors are reported in parentheses. *,**, and *** denote statistical significance at the $10 \%, 5 \%$, and $1 \%$ levels.

\section{Panel A. Voluntary Turnover Subsample}

\begin{tabular}{|c|c|c|c|c|c|c|}
\hline \multirow{3}{*}{$\begin{array}{l}\text { Dependent variable } \\
\text { CSR Horizon }\end{array}$} & \multicolumn{3}{|c|}{ Prob(Finding a new job) } & \multicolumn{3}{|c|}{ Prob(Finding a job in a public firm) } \\
\hline & 1 Year & 2 Years & 3 Years & 1 Year & 2 Years & 3 Years \\
\hline & $\begin{array}{l}\text { Coeff. } \\
\text { (SE) }\end{array}$ & $\begin{array}{l}\text { Coeff. } \\
\text { (SE) }\end{array}$ & $\begin{array}{l}\text { Coeff. } \\
\text { (SE) }\end{array}$ & $\begin{array}{l}\text { Coeff. } \\
\text { (SE) }\end{array}$ & $\begin{array}{l}\text { Coeff. } \\
(\mathrm{SE})\end{array}$ & $\begin{array}{l}\text { Coeff. } \\
\text { (SE) }\end{array}$ \\
\hline CSR FIRM & $\begin{array}{l}0.0971 * * \\
(0.0452)\end{array}$ & $\begin{array}{l}0.1234 * * * \\
(0.0348)\end{array}$ & $\begin{array}{l}0.1082 * * * \\
(0.0389)\end{array}$ & $\begin{array}{l}0.0812 * \\
(0.0523)\end{array}$ & $\begin{array}{l}0.0955^{* * *} \\
(0.0320)\end{array}$ & $\begin{array}{l}0.0800 * * \\
(0.0375)\end{array}$ \\
\hline $\log (\mathrm{SIZE})$ & $\begin{array}{l}0.0205 \\
(0.0149)\end{array}$ & $\begin{array}{l}0.0243 \\
(0.0136)\end{array}$ & $\begin{array}{l}0.0282 * \\
(0.0128)\end{array}$ & $\begin{array}{l}0.0231 \\
(0.0236)\end{array}$ & $\begin{array}{l}0.0235 \\
(0.0244)\end{array}$ & $\begin{array}{l}0.0297 \\
(0.0224)\end{array}$ \\
\hline ROA & $\begin{array}{l}0.0073 * * \\
(0.0031)\end{array}$ & $\begin{array}{l}0.0069 * \\
(0.0033)\end{array}$ & $\begin{array}{l}0.0068 \\
(0.0060)\end{array}$ & $\begin{array}{l}0.0030 \\
(0.0028)\end{array}$ & $\begin{array}{l}0.0039 \\
(0.0035)\end{array}$ & $\begin{array}{l}0.0086^{* *} \\
(0.0038)\end{array}$ \\
\hline RET & $\begin{array}{l}0.6728 \\
(0.4600)\end{array}$ & $\begin{array}{l}0.4677 \\
(0.8450)\end{array}$ & $\begin{array}{l}1.6481 \\
(1.1561)\end{array}$ & $\begin{array}{l}1.8409 \\
(1.0862)\end{array}$ & $\begin{array}{l}1.5549 \\
(1.0729)\end{array}$ & $\begin{array}{l}1.4312 \\
(0.8603)\end{array}$ \\
\hline $\log (\mathrm{AGE})$ & $\begin{array}{l}-1.9352 * * * \\
(0.2386)\end{array}$ & $\begin{array}{l}-1.9136^{* * *} \\
(0.2372)\end{array}$ & $\begin{array}{l}-1.9166^{* * *} \\
(0.2360)\end{array}$ & $\begin{array}{l}-0.8825^{* * *} \\
(0.1809)\end{array}$ & $\begin{array}{l}-0.8804 * * * \\
(0.2083)\end{array}$ & $\begin{array}{l}-0.8498 * * * \\
(0.2290)\end{array}$ \\
\hline Log(TENURE) & $\begin{array}{l}-0.1353 * * * \\
(0.0435)\end{array}$ & $\begin{array}{l}-0.1295 * * \\
(0.0448)\end{array}$ & $\begin{array}{l}-0.1323 * * \\
(0.0431)\end{array}$ & $\begin{array}{l}-0.0530 \\
(0.0389)\end{array}$ & $\begin{array}{l}-0.0633 \\
(0.0364)\end{array}$ & $\begin{array}{l}-0.0651 \\
(0.0368)\end{array}$ \\
\hline RESTATE & $\begin{array}{l}-0.5327 * * * \\
(0.0828)\end{array}$ & $\begin{array}{l}-0.5422 * * * \\
(0.0823)\end{array}$ & $\begin{array}{l}-0.5280 * * * \\
(0.0868)\end{array}$ & $\begin{array}{l}-0.0817 \\
(0.0518)\end{array}$ & $\begin{array}{l}-0.0973^{*} \\
(0.0541)\end{array}$ & $\begin{array}{l}-0.0988^{*} \\
(0.0497)\end{array}$ \\
\hline
\end{tabular}




\begin{tabular}{|c|c|c|c|c|c|c|}
\hline Industry FE & Included & Included & Included & Included & Included & Included \\
\hline Year FE & Included & Included & Included & Included & Included & Included \\
\hline Adjusted $\mathrm{R}^{2}$ & 0.2586 & 0.2532 & 0.2547 & 0.1262 & 0.1077 & 0.1094 \\
\hline $\mathrm{N}$ & 260 & 270 & 271 & 260 & 270 & 271 \\
\hline
\end{tabular}


Panel B. Forced Turnover Subsample

\begin{tabular}{|c|c|c|c|c|c|c|}
\hline \multirow{2}{*}{$\begin{array}{l}\text { Dependent } \\
\text { CSR Horizon }\end{array}$} & \multicolumn{3}{|c|}{ Prob(Finding a new job) } & \multicolumn{3}{|c|}{ Prob(Finding a job in a public firm) } \\
\hline & 1 Year & 2 Years & 3 Years & 1 Year & 2 Years & 3 Years \\
\hline & $\begin{array}{l}\text { Coeff. } \\
(\mathrm{SE})\end{array}$ & $\begin{array}{l}\text { Coeff. } \\
(\mathrm{SE})\end{array}$ & $\begin{array}{l}\text { Coeff. } \\
\text { (SE) }\end{array}$ & $\begin{array}{l}\text { Coeff. } \\
(\mathrm{SE})\end{array}$ & $\begin{array}{l}\text { Coeff. } \\
(\mathrm{SE})\end{array}$ & $\begin{array}{l}\text { Coeff. } \\
(\mathrm{SE})\end{array}$ \\
\hline CSR FIRM & $\begin{array}{l}0.0158 \\
(0.0550)\end{array}$ & $\begin{array}{l}0.0248 \\
(0.0424)\end{array}$ & $\begin{array}{l}0.0404 \\
(0.0397)\end{array}$ & $\begin{array}{l}-0.0386 \\
(0.0414)\end{array}$ & $\begin{array}{l}-0.0027 \\
(0.0404)\end{array}$ & $\begin{array}{l}0.0390 \\
(0.0307)\end{array}$ \\
\hline $\log (\mathrm{SIZE})$ & $\begin{array}{l}0.0166 \\
(0.0168)\end{array}$ & $\begin{array}{l}0.0136 \\
(0.0163)\end{array}$ & $\begin{array}{l}0.0186 \\
(0.0169)\end{array}$ & $\begin{array}{l}-0.0178 * \\
(0.0096)\end{array}$ & $\begin{array}{l}-0.0231 * \\
(0.0120)\end{array}$ & $\begin{array}{l}-0.0286^{*} \\
(0.0138)\end{array}$ \\
\hline ROA & $\begin{array}{l}0.0026 \\
(0.0054)\end{array}$ & $\begin{array}{l}0.0075 \\
(0.0045)\end{array}$ & $\begin{array}{l}0.0085 \\
(0.0063)\end{array}$ & $\begin{array}{l}-0.0026 \\
(0.0025)\end{array}$ & $\begin{array}{l}-0.0037 * * \\
(0.0012)\end{array}$ & $\begin{array}{l}-0.0019 \\
(0.0024)\end{array}$ \\
\hline RET & $\begin{array}{l}0.3272 \\
(0.8418)\end{array}$ & $\begin{array}{l}0.1477 \\
(0.8359)\end{array}$ & $\begin{array}{l}0.5372 \\
(0.8849)\end{array}$ & $\begin{array}{l}0.5899 \\
(0.3731)\end{array}$ & $\begin{array}{l}0.8008 \\
(0.7185)\end{array}$ & $\begin{array}{l}1.3272 \\
(0.7944)\end{array}$ \\
\hline $\log (\mathrm{AGE})$ & $\begin{array}{l}-0.4955 \\
(0.5021)\end{array}$ & $\begin{array}{l}-0.5895 \\
(0.4416)\end{array}$ & $\begin{array}{l}-0.6241 \\
(0.4429)\end{array}$ & $\begin{array}{l}0.2022 \\
(0.1320)\end{array}$ & $\begin{array}{l}0.1484 \\
(0.1333)\end{array}$ & $\begin{array}{l}0.1504 \\
(0.1378)\end{array}$ \\
\hline Log(TENURE) & $\begin{array}{l}-0.1168 * * \\
(0.0512)\end{array}$ & $\begin{array}{l}-0.1159 * \\
(0.0600)\end{array}$ & $\begin{array}{l}-0.1287 * \\
(0.0586)\end{array}$ & $\begin{array}{l}-0.0624 * \\
(0.0319)\end{array}$ & $\begin{array}{l}-0.0677 * * \\
(0.0280)\end{array}$ & $\begin{array}{l}-0.0706^{* *} \\
(0.0298)\end{array}$ \\
\hline RESTATE & $\begin{array}{l}0.0130 \\
(0.1394)\end{array}$ & $\begin{array}{l}0.0251 \\
(0.1428)\end{array}$ & $\begin{array}{l}0.0168 \\
(0.1511)\end{array}$ & $\begin{array}{l}0.1145 \\
(0.1229)\end{array}$ & $\begin{array}{l}0.1037 \\
(0.1367)\end{array}$ & $\begin{array}{l}0.0957 \\
(0.1430)\end{array}$ \\
\hline Industry FE & Included & Included & Included & Included & Included & Included \\
\hline Year FE & Included & Included & Included & Included & Included & Included \\
\hline Adjusted $\mathrm{R}^{2}$ & 0.1232 & 0.1357 & 0.1372 & 0.0291 & 0.0321 & 0.0374 \\
\hline $\mathrm{N}$ & 241 & 251 & 252 & 241 & 251 & 252 \\
\hline
\end{tabular}

